\title{
Geology of Rare Metals in Egypt- A review
}

\author{
Hassan Baioumy \\ Received 12 January 2021 \\ Revised 9 February 2021 \\ Accepted for publication 10 February 2021 \\ Published online: 30 June 2021
}

Minerals Technology Division, Central Metallurgical R \& D Institute (CMRDI), P.O. Box 87 Helwan, Cairo, Egypt

Corresponding author: E-mail: hassanbaioumy@hotmail.com, Tel.: +201016104679, Fax: +227142451

\section{Abstract}

The term "rare metals" refers in this work to metals with a low availability in natural. Based on their chemistry, rare metals were classified into; 1) rare earth elements (La-Lu), 2) trace elements (Nb, Ta, Mo, Cu, Ni, Co, Sn, W, V), 3) noble elements ( $\mathrm{Au}, \mathrm{Ag}$, and PGE) and 4) fissionable elements ( $\mathrm{U}$ and $\mathrm{Th}$ ). In Egypt, rare earth elements occur in the phosphorites, monazite and granites. Trace elements occur in three associations; a) elements in granites and albite granites such as $\mathrm{Nb}, \mathrm{Ta}, \mathrm{Sn}, \mathrm{Mo}$, and $\mathrm{W}, \mathrm{b}$ ) elements associate mafic rocks and ophiolites include $\mathrm{Cu}, \mathrm{Ni}$, and $\mathrm{Co}$, and c) V in the black shales. 95 Au localities were reported mainly as vein-type mineralization in the Eastern Desert. PGE are confined to three associations including mafic and ultramafic rocks, chromite and black shales as sulfides, alloys, and organometallic compounds, respectively. Uranium occurs in granites of the Eastern Desert. Thorium was reported at the Um Ara area at the Eastern Desert and in the monazite from the black sands. Although rare metals are quite common in Egypt, processing and beneficiations of the rare metals-bearing rocks did not reflect the abundance and the economic significance of these metals.

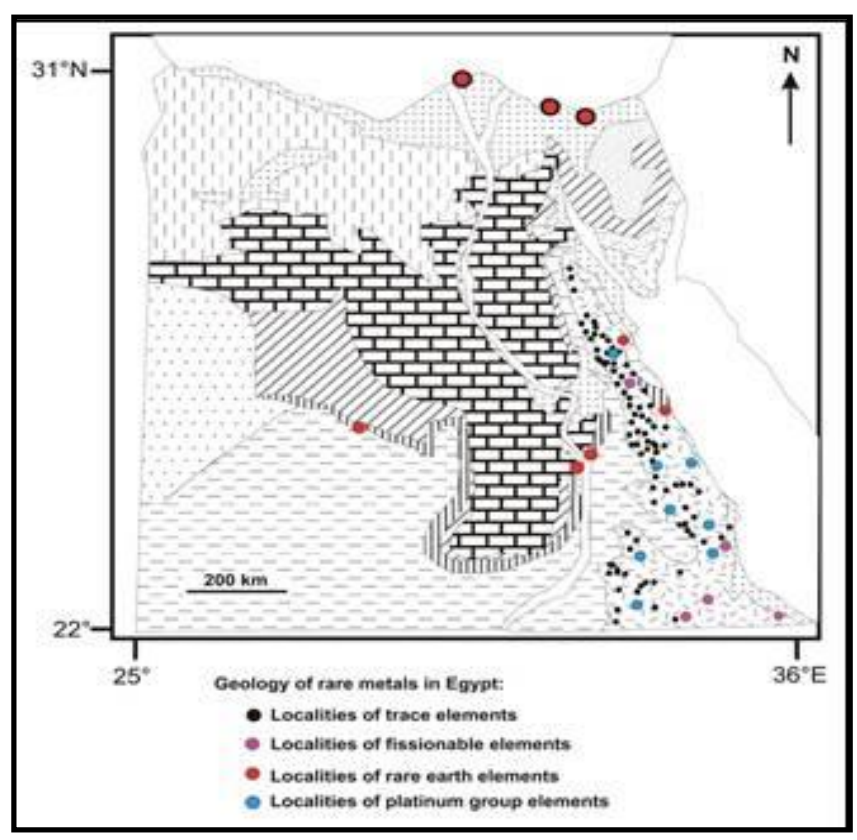

Keywords: Rare Earth Elements; Trace Elements; Noble Elements; Fissionable Elements; Egypt

\section{Introduction}

The term "rare metals" is not strictly defined $[1,2,3]$. According to Simandl [3], it refers mainly to

uncommon, nonferrous metals used in small quantities, typically < 150000 tones/year, or derived from 
geographically restricted areas. Behrendt et al. [2] suggested three definitions for the rare metals. 1) Rare metals are the expensive metals or whose price has increased intensely. 2) Rare metals are metals with a low present availability. 3) Rare metals are metals which are only mined in a few countries. They analyzed several arguments for the "rarity" of metals using the following measures:

- Price: metal prices of almost 500 USD per $\mathrm{kg}$;

- Price increase: an increase in the price of metals in more than $100 \%$ in 2001 to 2004- Shortage of reserves: reserves lasting less than 25 years, based on production statistics in 2004;

- Concentration in quantity and value chain or high concentration of reserves.

In Japan, the term rare is frequently used to refer to the 47 metal elements, based on the definition established by the Ministry of Economic, Trade and Industry. There are a total of 89 elements in the natural world and over half of these elements are rare metals [2]. In this paper, definition 2 of Behrendt et al. [2] that rare metals are metals with a low availability, will be used. Based on their chemical properties and association, rare metals are classified in this work into four groups (Fig. 1) including: (1) rare earth elements
(REE) of the 14 lanthanide elements from $\mathrm{La}$ to $\mathrm{Lu}$ as they behave similarly and occur as a group in rocks and minerals, (2) trace elements including elements occur in relatively low concentrations ( $\mathrm{ppm}$ ) and usually present in rocks and minerals as associations include a number of elements, (3) noble elements include precious elements particularly platinum group elements (PGE) and gold, and (4) fissionable elements include radioactive elements particularly $U$ and $T h$. The applications, markets, characterizations, and occurrences in Egypt of these metals will also follow this classification scheme.

Due to their vast industrial applications particularly in electronic and automobile industries, the need of rare metals has amplified intensely in the last few decades $[4,5]$. Thus, finding additional resources of the rare metals is vital to bridge the increasing gab between production and needs. This work shows a critical review of the potential occurrences of rare metals in Egypt that can be an important source of these metals to the regional and global markets. The review focuses on the localities, concentrations (geochemistry), the modes of occurrences (mineralogy), and origin of the rare metals in Egypt.

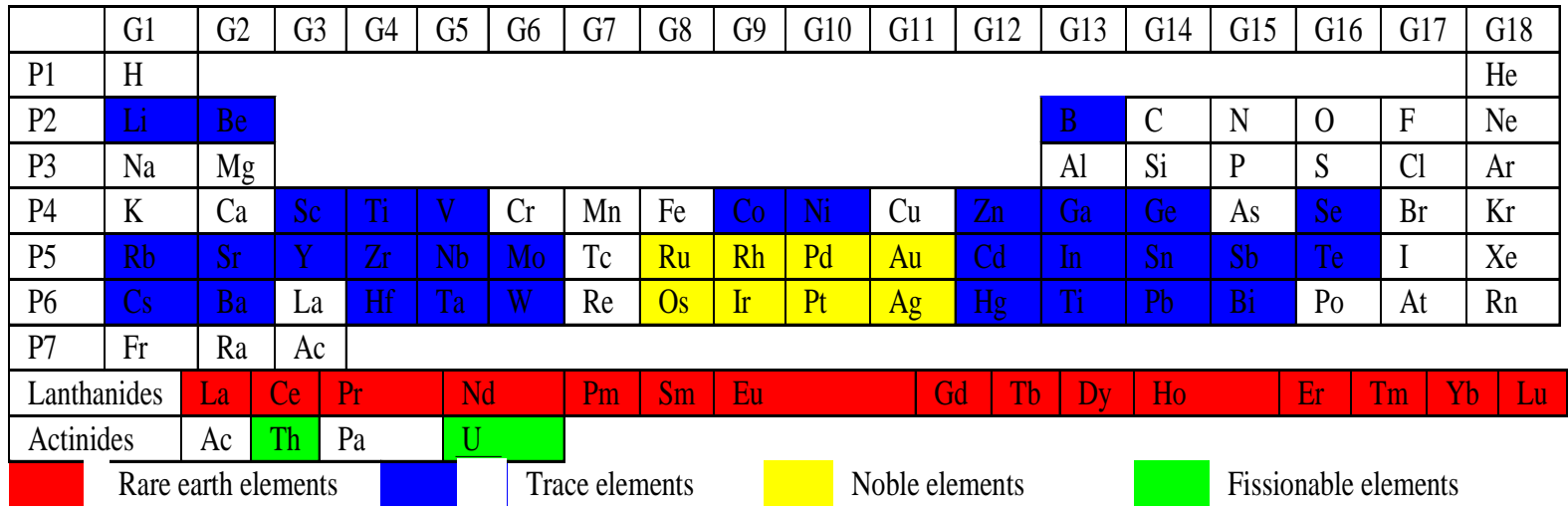

Fig. 1 Classification of rare metals into four groups based on their chemical properties.

\section{Occurrences of rare metals in Egypt}

This review will follow the abovementioned classification of rare metals into rare earth elements, trace, noble, and fissionable elements.

\subsection{Rare earth elements (REE)}

Three potential occurrences of REE-bearing rocks in Egypt include phosphorites, black sands, and granites.
The occurrences of these rocks in economic scale are shown in Figure 2.

\subsubsection{Phosphorites}

Phosphorite deposits that belong to the Duwi Formation represent one of the major deposits of economic importance in Egypt. Phosphatic deposits comprise a part of the widespread late CretaceouseEocene Tethyan phosphogenesis. Huge quantities of phosphorites $(\sim 30 \times 109 \mathrm{~T})$ were accumulated in this 


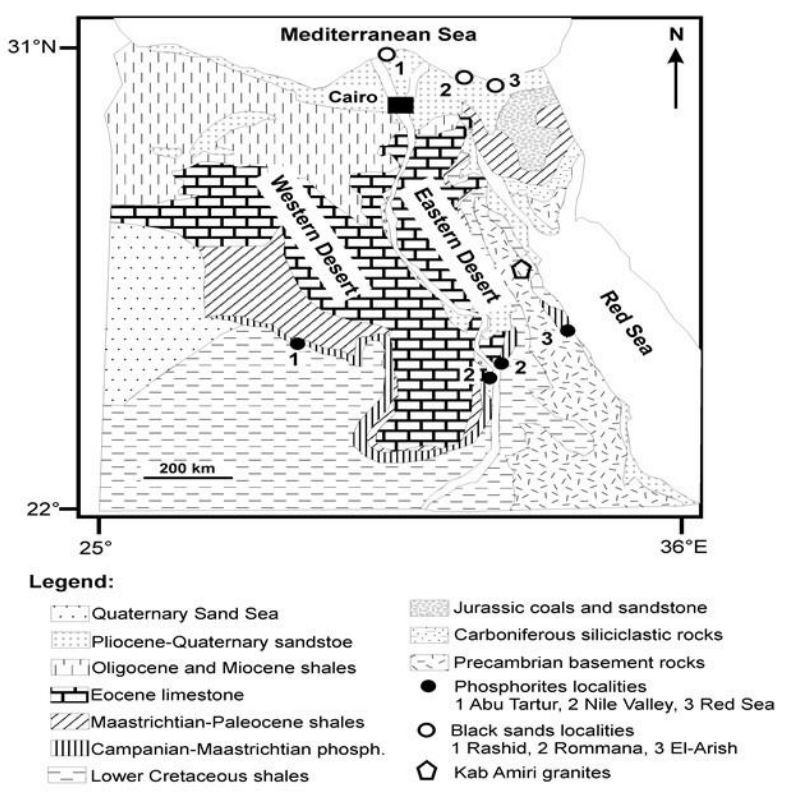

Fig. 2 Geological map of Egypt showing the potential occurrences of REE-bearing rocks (modified from [6]).

phosphogenic province, including 7 x $109 \mathrm{~T}$ deposited in the Middle East area [7]. The phosphorite resources in Egypt only are more than 3 billion metric tons (Notholt, 1985). They are exploited from three regions in the Red Sea, Nile Valley, and Abu-Tartur areas in what is called "the phosphorite belt" (Fig. 2).

Abu Tartur area is considered as the highest phosphate reserve in Egypt, the reserve is estimated to be about 2 billion metric tons [8]. Apatite $\left(\mathrm{Ca}_{5}\left(\mathrm{PO}_{4}\right)_{3}(\mathrm{OH}, \mathrm{F}, \mathrm{Cl})\right)$ is the major constituent of these phosphorites beside nonphosphatic constituents such as detrirtal quartz, glauconite, pyrite, dolomite, calcite, gypsum, and anhydrite $[9,10]$.

Rare earth elements distributions in the Red Sea, Nile Valley, and Abu-Tartur phosphorites are displayed in Table 1 [11]. The Abu-Tartur deposit exhibit higher rare earth elements concentrations (average $685 \mathrm{ppm}$ ) relative to the Red Sea (average $212 \mathrm{ppm}$ ) and Nile Valley (average $165 \mathrm{ppm}$ ) phosphorites. Awadalla [12] reported concentrations of REE in the Abu Tartur phosphorites ranging from 518 to $1011 \mathrm{ppm}$. EPMA mapping of the apatite grains showed homogeneous distributed of REE in the grains (Fig. 3) [12] suggesting the occurrence of these elements in the structure of apaptite replacing $\mathrm{Ca}$. This was also confirmed by the general positive correlations between $\Sigma$ REE and the $\mathrm{P}_{2} \mathrm{O}_{5}$ contents (Fig. 4) [12]. According to Baioumy [11], the high REE concentrations in the Abu Tartur phosphorites relative to other areas, suggested postdepositional alterations of the REEs contents and patterns during diagenesis due to the deposition of these deposits in different depositional environments.

\subsubsection{Black sands}

Black sand deposits of Egypt are beach placers accumulated from the Nile River during flood seasons arrive the Mediterranean Sea at river mouth [13]. Figure 2 displays the distribution of the black sands in Egypt alongside the Mediterranean Sea coast from Rafah East to Alexandria West. Black sands comprise several economic minerals such as magnetite, ilmenite, hematite, zircon, rutile, monazite and garnet. The reserves of economic minerals at Rashid area are shown in Table 2 [13].
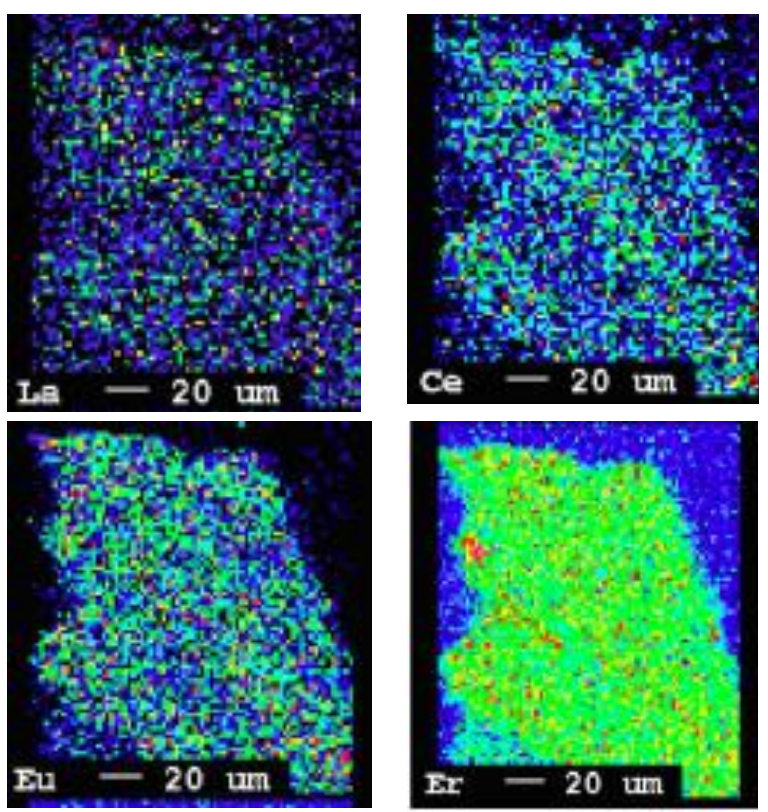

Fig. 3 EPMA elemental mapping of the apatite grains from the Abu Tartur area showing the homogeneous distributions of REE in the apatite grains [12].

At Rommana and Al Arish areas that cover an area of $18 \mathrm{~km}^{2}$, the proved reserves of black sands calculated to a depth of $1 \mathrm{~m}$ are around 88 million tons, while the proved reserves to a depth of $10 \mathrm{~m}$ are estimated by 3 million tons [14]. REE occur in the black sands mainly in the monazite $\left((\mathrm{Ce}, \mathrm{La}, \mathrm{Nd}, \mathrm{Th}) \mathrm{PO}_{4}\right)$. Although, the black sands in Egypt are quite common and have economic importance and can be considered as important source of REE, no much information available about the concentrations of REE in the bulk 
samples and/or in the separated monazite from these black sands.

Table 1. Average REE concentrations (ppm) in the phosphorites, Egypt (modified from [11]).

\begin{tabular}{|l|l|l|l|}
\hline & Red Sea & Nile Valley & Abu Tartur \\
\hline $\mathrm{La}$ & 44.5 & 39.5 & 156.6 \\
\hline $\mathrm{Ce}$ & 71.6 & 53.4 & 164.1 \\
\hline $\mathrm{Pr}$ & 10.7 & 7.5 & 36 \\
\hline $\mathrm{Nd}$ & 43 & 31.5 & 154.4 \\
\hline $\mathrm{Sm}$ & 8.2 & 6.2 & 31.4 \\
\hline $\mathrm{Eu}$ & 2.2 & 1.7 & 8.9 \\
\hline $\mathrm{Gd}$ & 9 & 6.9 & 34.9 \\
\hline $\mathrm{Tb}$ & 1.2 & 1 & 5.4 \\
\hline $\mathrm{Dy}$ & 9 & 6.6 & 33.2 \\
\hline $\mathrm{Ho}$ & 1.9 & 1.7 & 7.5 \\
\hline $\mathrm{Er}$ & 5.5 & 4.6 & 21.3 \\
\hline $\mathrm{Tm}$ & 0.7 & 0.6 & 2.9 \\
\hline $\mathrm{Yb}$ & 4.5 & 4.1 & 18.2 \\
\hline $\mathrm{Lu}$ & 0.8 & 0.7 & 2.9 \\
\hline $\mathrm{KREEs}$ & 212.8 & 165.6 & 684.6 \\
\hline
\end{tabular}
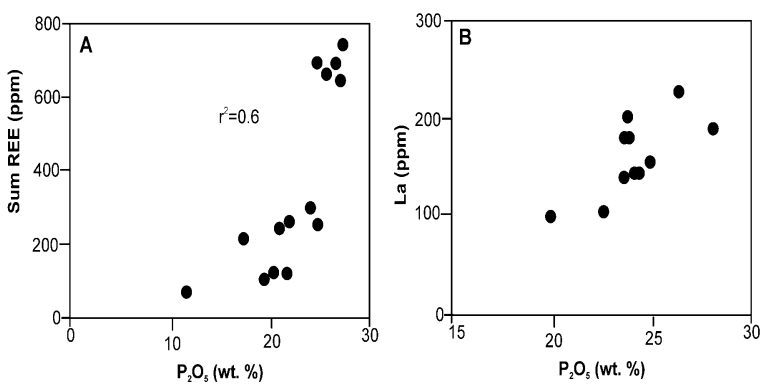

Fig. 4 A) General positive correlation between $\mathrm{P}_{2} \mathrm{O}_{5}$ and $\Sigma$ REE in the Egyptian phosphorites (data from [11], B) positive correlation between $\mathrm{P}_{2} \mathrm{O}_{5}$ and $\mathrm{La}$ in Abu Tartur deposits (data from [12]).

\subsubsection{Granites}

Granites are widely distributed in the Eastern desert and Sinai as a major constituent of the Basement Rocks in these areas. These granites can be a potential source of REEs. At the Kab Amiri area, which is situated nearby the Qena-Safaga Road (Fig. 2), two radioactive anomalies have been described in the Kab Amiri monsogranite: one in the silica veinlets and the other in the pegmatites. The pegmatites are made of quartz cores bounded by alkali feldspar $[15,16,17,18,19]$. The pegmatites show exceptionally high REE concentrations The distributions of REE of Kab Amiri deposits in different grain sizes are shown in Table 3.

Table 2. Reserves of economic minerals in the Rashid East (data from [13]

\begin{tabular}{|l|l|}
\hline Mineral & Reserves (1000 tons) \\
\hline Ilmenite & 2087 \\
\hline Magnetite & 1437 \\
\hline Hematite & 214 \\
\hline Sulphides & 86 \\
\hline Zircon & 81 \\
\hline Garnet & 72 \\
\hline Monazite & 31 \\
\hline Rutile & 29 \\
\hline
\end{tabular}

Table 3. Distributions of REE of Kab Amiri deposits in various grain sizes (data from [15]).

\begin{tabular}{|l|l|l|}
\hline Grain Size $(\mu \mathrm{m})$ & Weight $(\%)$ & $\mathrm{REE}_{2} \mathrm{O}_{3}(\%)$ \\
\hline-500 & 8.2 & 14.2 \\
\hline-420 & 6.6 & 10.7 \\
\hline-297 & 6.1 & 9.1 \\
\hline-250 & 10.6 & 14.6 \\
\hline-125 & 17.2 & 15.8 \\
\hline-74 & 51.3 & 35.6 \\
\hline
\end{tabular}

\subsection{Trace elements}

Trace elements in Egypt are quite common and in many cases they occur in association of more than one metal. Figure 5 shows the localities of trace elements in Egypt mainly in the granites and mafic igneous rocks in the Eastern Desert [20].

\subsubsection{Niobium-Tantalum}

In Egypt, niobium and tantalum mineralization occurs in the hard rock deposits and their associated placers in the Precambrian basement rocks of the South Eastern Desert in what is called albite granite. Most of the known occurrences are south of $26^{\circ} \mathrm{N}$ latitude and east of $34^{\circ} \mathrm{E}$ longitudes particularly in Abu Dabab, Nuweibe, Abu Rashid, Um Naqat and Zabara areas (Fig. 5) [21,22]. According to Helba, et al. [21], Ta contents in the whole rock range between 63 and 155 ppm, while $\mathrm{Nb}$ contents range between 61 and 87 ppm. Table 4 summarizes the $\mathrm{Ta}-\mathrm{Nb}$ ores in these localities based on the Gippsland Co. reports [23,24]. 


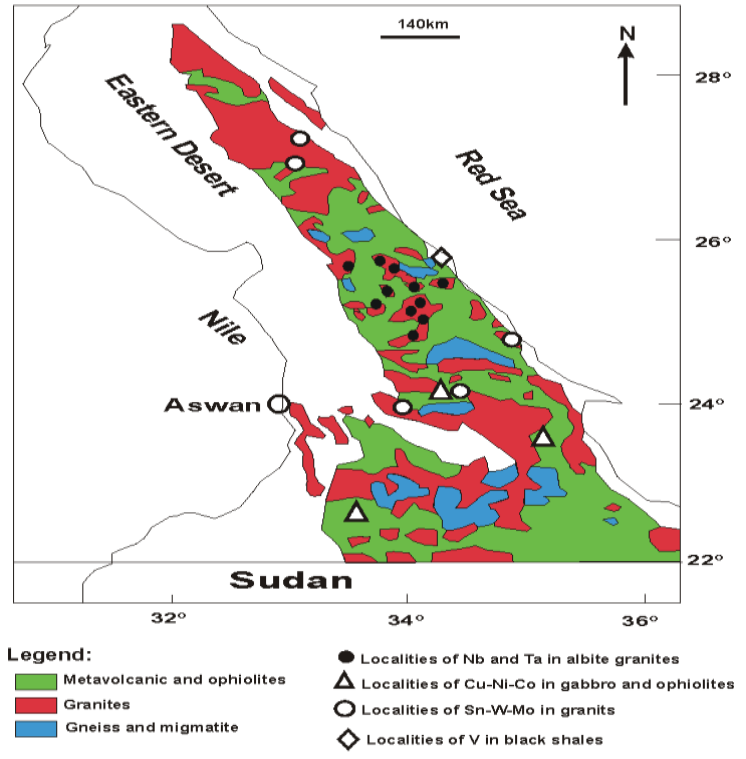

Fig. 5 Basement complex in the Eastern Desert showing the potential occurrences of trace elementsbearing rocks (modified from [20]).

Table 4. The $\mathrm{Ta}-\mathrm{Nb}$ ores in the Eastern Desert (data from $[23,24]$.

\begin{tabular}{|c|c|c|}
\hline Location & $\begin{array}{l}\text { Reserves } \\
\text { (million tons) }\end{array}$ & $\begin{array}{l}\text { Average } \\
\text { concentrations of } \mathrm{Nb} \\
\text { and } \mathrm{Ta}\end{array}$ \\
\hline \multirow{2}{*}{$\begin{array}{l}\text { Abu } \\
\text { Dabbab }\end{array}$} & \multirow{2}{*}{40} & 0.27 wt. $\% \mathrm{Ta}_{2} \mathrm{O}_{5}$ \\
\hline & & 0.020 wt. $\% \mathrm{Nb}_{2} \mathrm{O}_{5}$ \\
\hline \multirow{2}{*}{ Nuweibi } & \multirow{2}{*}{115} & 0.017 wt. $\% \mathrm{Ta}_{2} \mathrm{O}_{5}$ \\
\hline & & 0.015 wt. $\% \mathrm{Nb}_{2} \mathrm{O}_{5}$ \\
\hline \multirow{2}{*}{ Um Naggat } & \multirow{2}{*}{25} & 0.022 wt. $\% \mathrm{Ta}_{2} \mathrm{O}_{5}$ \\
\hline & & 0.20 wt. $\% \mathrm{Nb}_{2} \mathrm{O}_{5}$ \\
\hline \multirow{2}{*}{ Abu Rashid } & \multirow{2}{*}{ Not Calculated } & 0.033 wt. $\% \mathrm{Ta}_{2} \mathrm{O}_{5}$ \\
\hline & & 0.30 wt. $\% \mathrm{Nb}_{2} \mathrm{O}_{5}$ \\
\hline
\end{tabular}

Tantalite-columbite is the major ore mineral in these areas [21]. Other Ta-Nb- Sn-bearing phases recognized in the SEM-EDS analysis containing ixiolite having up to11 wt. \% $\mathrm{SnO}_{2}$, stibiotantalite with $\mathrm{Sb}_{2} \mathrm{O}_{3}$ up to 6 wt. $\%$, cassiterite and microlite. Tantalite-columbite occurs as subhedral to euhedral, fine-grained $(0.05-0.2 \mathrm{~mm})$ bladed crystals in two major generations: 1) as inclusions in muscovite (usually associated with zircon and iron oxides) in quartz phenocrysts (Fig. 6A), and in beryl and topaz crystals; 2) as disseminated grains in the matrix constituents in both western and eastern areas. Zircon (Hf-, Th-, U-rich) has been also detected in columbite-tantalite (Fig. 6B).

Under SEM tantalite-columbite commonly display zoning textures, where rims show constantly higher $\mathrm{Ta}$ than the cores (Ta-rich borders look brighter in the SEM images) (Fig. 7) [21]. According to Abdalla [21], $\mathrm{Nb}_{2} \mathrm{O}_{5}$ concentrations in the Columbite-tantalite mineral grains range between 17 and 76 wt. \%, while $\mathrm{Ta}_{2} \mathrm{O}_{5}$ concentrations vary from 0.7 to 63 wt. $\%$.

At the Kab Amiri area, Central Eastern Desert, ElHussaini et al., [15] reported high concentrations of $\mathrm{Nb}$ and $\mathrm{Ta}$ in the monsogranite (Table 5).
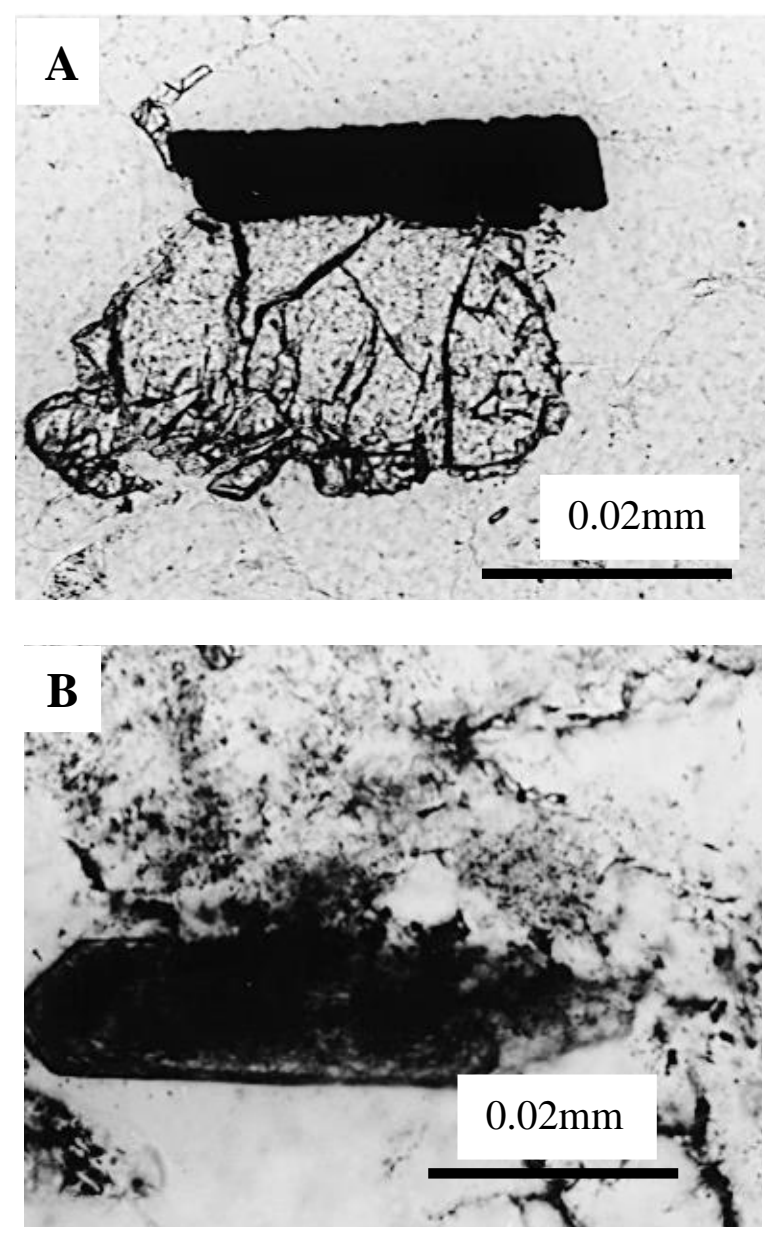

Fig. 6 A) Photomicrographs of tantalite-columbite grain (black) and garnet (high relief, grey) in quartz. (B) Prismatic zircon with partly metamict, cloudy core [21]. 


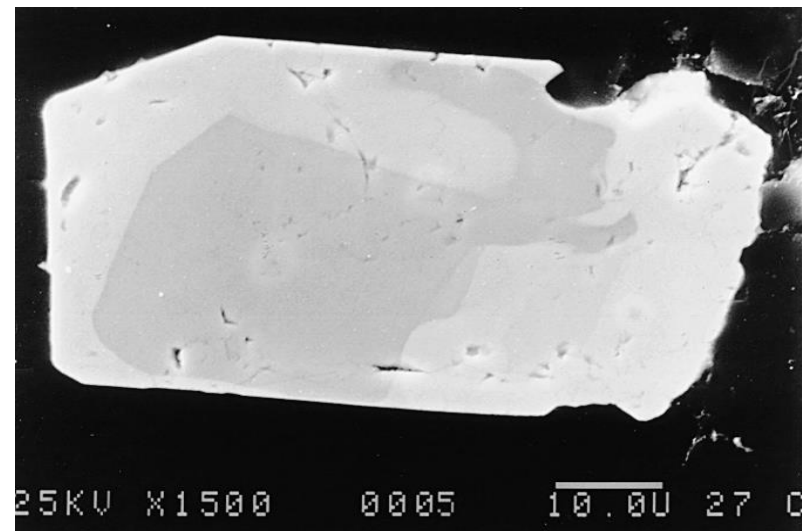

Fig. 7 SEM-photomicrograph of a discontinuously zoned tantalite-columbite crystal from the Nuweibi granite. The dark core (Ta-poor) and overgrowth of brighter Ta-rich parts [21].

El-Kammar et al. [25] considered the granites at G. Gattar as mineralized granites with a relative enrichment of $\mathrm{Nb}$ (average of $40 \mathrm{ppm}$ ). Carbonatite of the El Mansouri is characterized abnormal $\mathrm{Nb}$ (up to 3 wt. $\left.\% \mathrm{Nb}_{2} \mathrm{O}_{5}\right)$ as niocalite $\left(\mathrm{Ca}_{4} \mathrm{NbSi}_{2} \mathrm{O}_{10}(\mathrm{O}, \mathrm{F})\right)$ [26,27]. Anomalous concentrations of $\mathrm{Nb}(300 \mathrm{ppm})$ were reported in the carbonatites of Tarbtie South and El Naga [28]. Feldespathized nepheline syenites in El Naga, Nigrub, El Fogani, and Abu Khrug areas are associated with anomalous concentrations of $\mathrm{Nb}$ (13003000 ppm) [28].

\subsubsection{Copper-Nickel-Cobalt}

Copper-nickel-cobalt sulfide deposits occur in two assemblies in the mafic-ultramafic association in the gabbro members of the ophiolite sequences and in the layered intrusions. The two types occur in Egypt at Abu Swayel and El Geneina areas for the gabbro and Gabbro Akarem for the layered intrusions [29,28,30]. At Abu Swayel area, the ore body include both massive and dispersed mineralization presented in a lens-like body of amphibolite, $30 \mathrm{~m}$ wide and $500 \mathrm{~m}$ long [31]. The ore minerals contain pyrite, pyrrhotite, cubanite and ilmenite, chalcopyrite, pentlandite, bravoite, violarite, brochianite, malachite and chacanthite (Fig. 8A). Ore reserve have been estimated at 85,000 tons comprising 2.8 wt. $\% \mathrm{Cu}, 1.53$ wt. $\% \mathrm{Ni}$ with minor quantities of Co. At El Geneina, malachite and gamierite-stained gossan occur in mafic-ultramafic rocks that include peridotite, pyroxenite and gabbros. Ore minerals are represented mostly by pyrite, pyrrhotite, chalcopyrite, and pentlandite. Core assay indicated 0.17 wt. $\% \mathrm{Cu}$ and 0.38 wt. \% Ni [28]. At Gabbro Akarem area, disseminated and massive $\mathrm{Cu}-\mathrm{Ni}$ sulfide mineralization occur within a massive peridotite, norite and melanorite (Fig. 8B and C). Reserve assessed at 700,000 tons of mineralized peridotite as a grade of 0.95 wt. $\%$ with $\mathrm{Ni}$ and $\mathrm{Cu}$, of which 270,000 tons of grade 1.18 wt. $\% \mathrm{Ni}+\mathrm{Cu}$ [28]. At St John's Island, Red Sea, Ni-bearing veins occur as garnierite-bearing veins extend for about $50 \mathrm{~m}$ with a width varying from 0.6 to $2 \mathrm{~m}$ with a $\mathrm{Ni}$ content of 5 to 9 wt. \% [28,32].

Table 5. Distributions of $\mathrm{Nb}$ and $\mathrm{Ta}$ at $\mathrm{Kab}$ Amiri ore mineral in different grain sizes (data from [15]).

\begin{tabular}{|l|l|l|l|}
\hline $\begin{array}{l}\text { Grain Size } \\
(\mu \mathrm{m})\end{array}$ & Weight $(\%)$ & $\mathrm{Nb}_{2} \mathrm{O}_{5}(\%)$ & $\mathrm{Ta}_{2} \mathrm{O}_{5}(\%)$ \\
\hline-500 & 8.2 & 10.6 & 7.9 \\
\hline-420 & 6.6 & 8.4 & 6.4 \\
\hline-297 & 6.1 & 8.9 & 6.2 \\
\hline-250 & 10.6 & 8.7 & 13.2 \\
\hline-125 & 17.2 & 15.2 & 19.0 \\
\hline-74 & 51.3 & 48.2 & 47.4 \\
\hline
\end{tabular}

\subsubsection{Tin-Tungsten-Molybdenum}

Tin-Tungsten-Molybdenum mineralization has been categorized by Hussein [28] as deposits related to granites. Igla deposit is an example of the $\mathrm{Sn}-\mathrm{W}$ ores nearby Mersa Alam area (Fig. 9). Molybdenum mineralization presents as vein-type and disseminated at Abu Marwa, Gabal Gattar, Abu Harba, Homer Akarm and Um Disi areas [28]. Molybdenite-bearing quartz veins which cut through the 'Pink granite' distributed in the NED in six localities; Gabal Gattar, AbuHarba, Wadi Dib, Abu Marwa, Umm Disi, and Homret Akarem [33,34] with an average ore grade $0.031 \mathrm{Mo}$, and the reserves at about 8,000,000 tons [35]. W-bearing minerals generally associates with Snbearing minerals in Igla and Muelha areas where in the Igla area, $\mathrm{Sn}$ is up to $0.5 \%$ and $\mathrm{W}$ up to $0.06 \mathrm{wt}$. \%. Tin presents as vein-type and disseminated in Muelha, Abu Dabbab, Fatira, Abu Kharif, Nuweibi and Abu Hammad areas with geological reserves have been calculated by Anwar et al. [36] as 245000 tons Sn. 

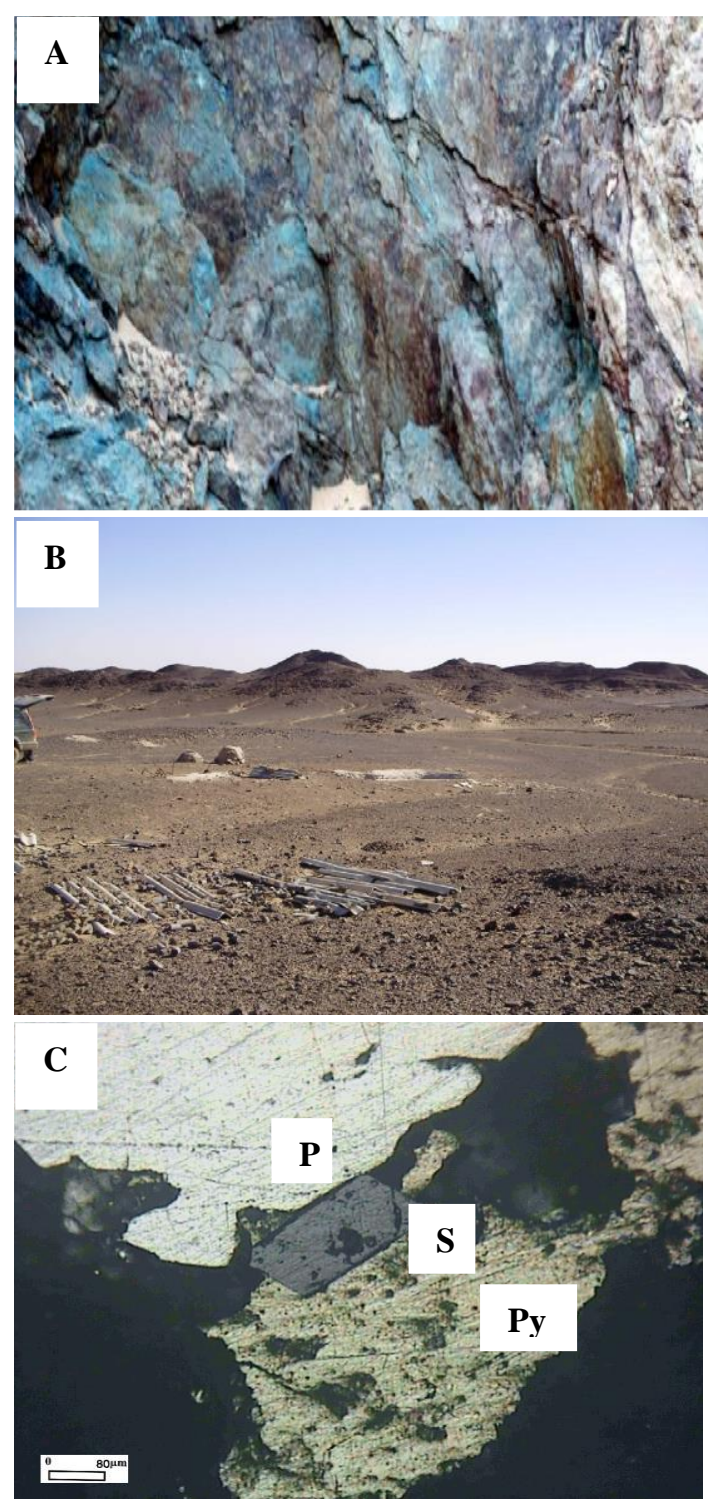

Fig. 8 (A) Photograph showing mineralized peridotite stained with malachite, Abu Swayel area. (B) Photograph showing mineralized peridotite in the Gabbro Akarem area. (C) Photomicrograph showing pyrrhotite (Py), pentlandite (P) and sphalerite (S) in the mineralized peridotite [30].

\subsubsection{Vanadium}

According to Baioumy and Ismael [37], black shales intercalated with the phosphorite deposits in the Red Sea area show considerably high vanadium contents (1056-2800 ppm).
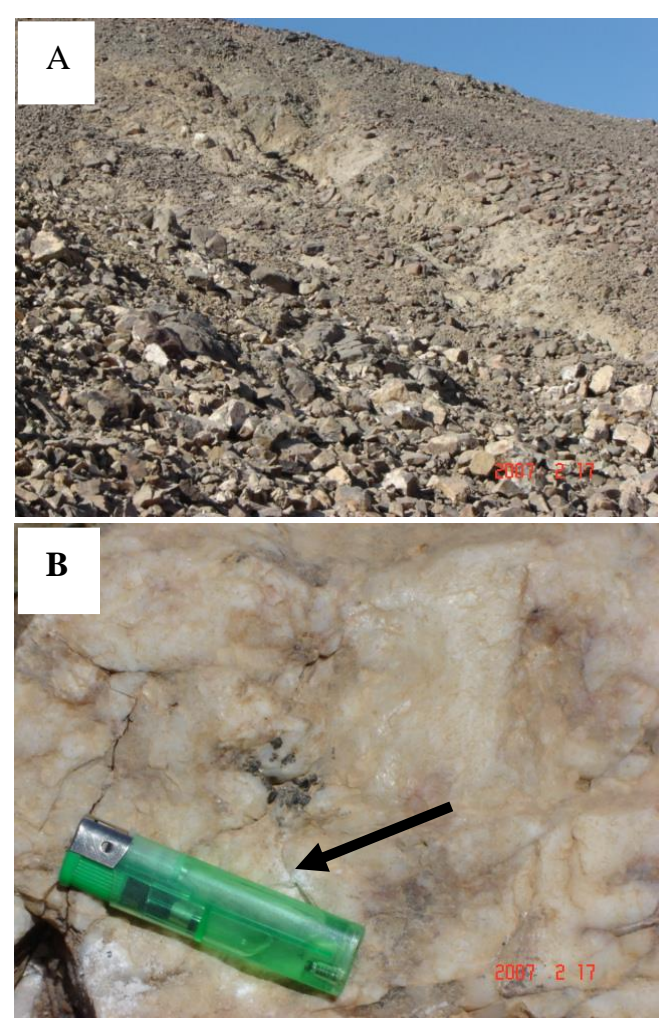

Fig. 9 A) Field photograph showing granite rocks at the Igla area. B) Cassiterite grains inside the quartz veins (arrows).

The vanadium contents (Table 6) exhibit positive correlation with the total organic carbon (TOC) in these shales (Fig. 10) suggesting the occurrence of the majority of the $\mathrm{V}$ in the organic fraction, probably as organomettalic component.

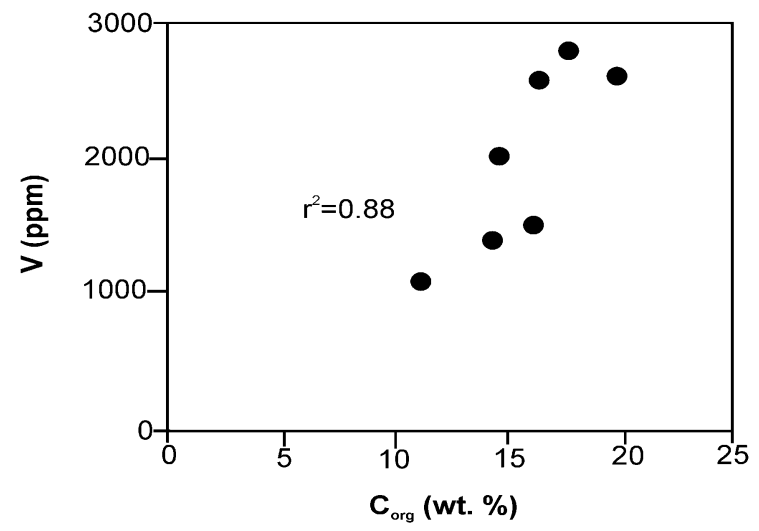

Fig. 10 Positive correlation between $\mathrm{V}$ and total organic carbon (TOC) in the black shales (data from [37]. 
Table 6. Distribution of $\mathrm{V}$ in the black shales from different phosphorite mines, Red Sea area (data from [37].

\begin{tabular}{|l|l|}
\hline Phosphorite mine & $\mathrm{V}(\mathrm{ppm})$ \\
\hline Galal & 2600 \\
\hline Islam & 1056 \\
\hline Younos & 2800 \\
\hline Water Flow & 2350 \\
\hline Tondob & 1270 \\
\hline
\end{tabular}

\subsection{Noble elements}

Noble elements in Egypt including Au, Ag and PGE occur in many localities mainly in the basement complex of the Eastern Desert (Fig. 11).

\subsubsection{Gold-Silver}

Gold is reported in Egypt in more than 95 localities, majority of them have been mined during Pharaonic period [38]. Botros [38] suggested a three-fold classification of gold mineralizations in Egypt related to the tectonic-magmatic development of the Nubian Shield. These include strata-bound, non-strata-bound and placer deposits. Strata-bound gold deposits were

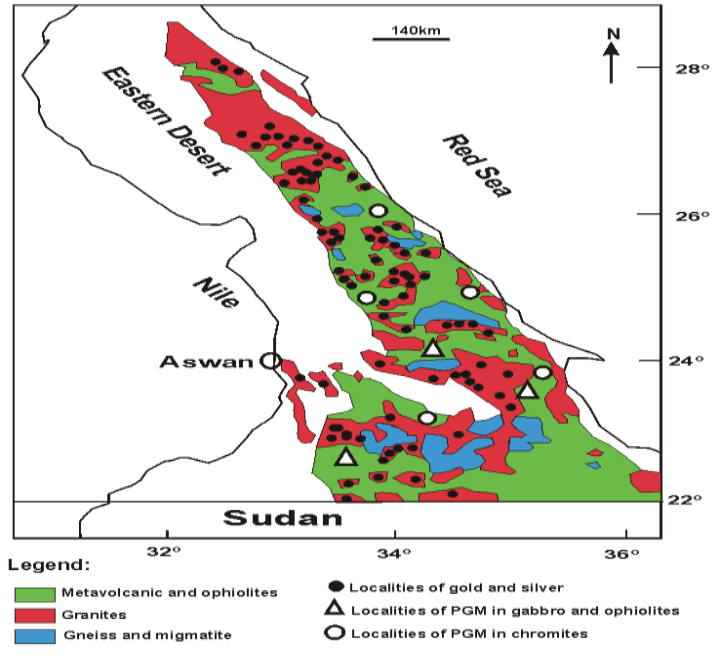

Fig. 11 Geological map of the basement complex in the Eastern Desert showing the potential occurrences of noble elements-bearing rocks (modified from [20]

further divided into three categories: gold-bearing Algoma-type Banded Iron Formation, gold-bearing volcanogenic massive sulphide and gold-bearing tuffaceous sediments deposits. The non-strata-bound deposits are subdivided into two major types: vein-type mineralization presented in a widespread range of rocks and disseminated-type mineralization held in hydrothermally altered rocks (alteration zones). Placer deposits have been divided into lithified and modern placers. Gold-bearing Algoma-type Banded Iron Formation was found at Abu Marawat gold [39,40]) and Um Nar areas [41]. Gold contents reach up to 2.15 $\mathrm{ppm}$ in the formation [39] bounded in the flaky hematite (Fig. 12A) and/or as fine inclusions in the magnetite (Fig. 12B).

Gold-bearing tuffaceous sediments are restricted in regions where volcanic and volcaniclastic rocks are closely intercalated with each other. The gold contents in the auriferous tuffaceous sediments is up to 11.62 ppm in Abu Marawat region [39].
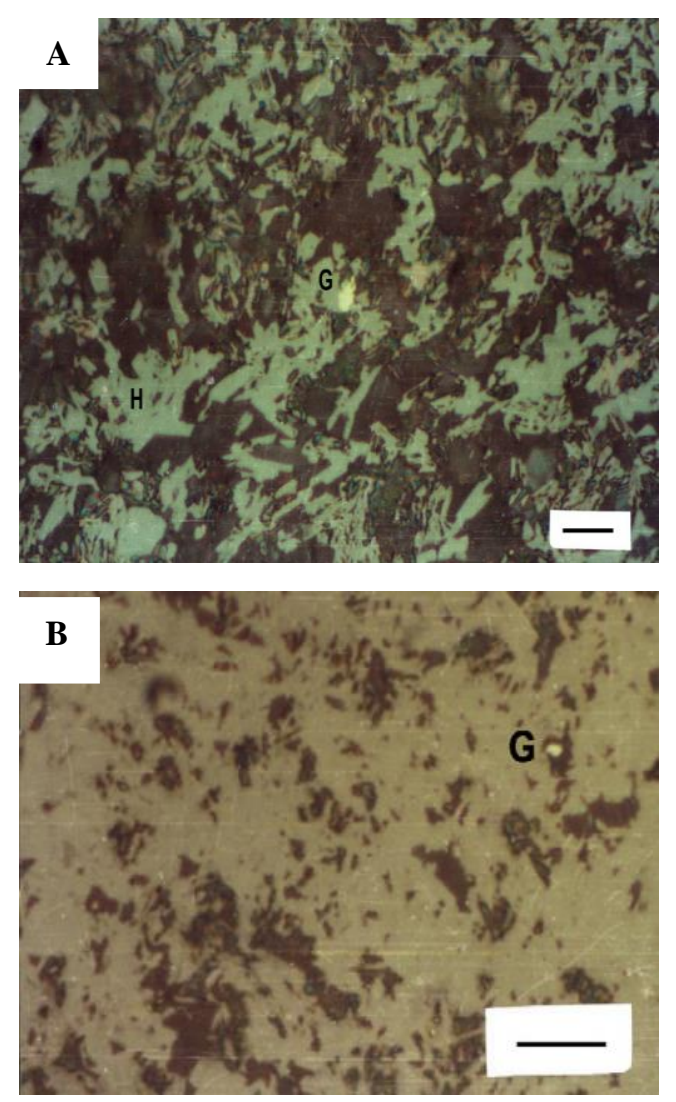

Fig. 12 A) Photomicrograph of gold grains (G) bounded in the hematic flake $(\mathrm{H})$. B) gold speck $(\mathrm{G})$ enclosed in the Fe-bearing minerals at Abu Marawat area [39]. 
Volcanic hosted massive sulphide (VHMS) rocks in the Eastern Desert are reported in Helgit, Um Samuki, Maakal, Abu Gurdi, Darhib, El Atshan and Egat areas.

Two different spatial and mineralogical associations of gold deposits are recorded in the volcanogenic massive sulphides and their alteration zones (the keel zone) in the Eastern Desert [38]: (1) Gold-silver-zinc association: In this association, gold content are very low (0.3-0.4 ppm) and silver is high, averaging 109 ppm in the Um Samuki VHMS deposit. 2) Gold-copper association:

This association classically presents in alteration zone of the footwall rock (the keel zone) and the basal parts of the massive sulphide deposit. Gold contents reach up to $5.5 \mathrm{ppm}$ with average of $1 \mathrm{ppm}$. Silver is very low, typically ranges from 4 to $10 \mathrm{ppm}$. Vein-type gold deposit constituted the core target for gold deposits since ancient ages, where ancient Egyptians mined gold from these veins in underground mines and open-pits. Table 7 summarizes the features of some vein-type gold deposits in Egypt.

Table 7. Some vein-type gold mineralization in the Eastern Desert, Egypt (data from [42,40,43].

\begin{tabular}{|c|c|c|}
\hline Area & Host rocks & Au content \\
\hline $\begin{array}{l}\text { Abu } \\
\text { Marawat }\end{array}$ & $\begin{array}{l}\text { Volcano-sedimentary } \\
\text { rocks intercalated with } \\
\text { diorite-tonalite }\end{array}$ & $\begin{array}{l}1.37-73.48 \\
\mathrm{~g} / \mathrm{t} \\
\text { (average } \\
6.9 \mathrm{~g} / \mathrm{t})\end{array}$ \\
\hline Erediya & Tonalite-granodiorite & $\begin{array}{l}13.2-29.76 \\
\mathrm{~g} / \mathrm{t}\end{array}$ \\
\hline Dungash & $\begin{array}{l}\text { Metavolcanic and } \\
\text { metapyroclastic Rocks }\end{array}$ & $\begin{array}{l}\text { Average } \\
3.87 \mathrm{~g} / \mathrm{t}\end{array}$ \\
\hline Umm Ud & $\begin{array}{l}\text { Metaandesite, metabasalt } \\
\text { and their tuffs intercalated } \\
\text { with schistose diorites. } \\
\text { Both are intruded by } \\
\text { quartz veinlers and veins }\end{array}$ & $\begin{array}{l}2-15 \quad \mathrm{~g} / \mathrm{t} \\
\text { (average } 3 \\
\mathrm{~g} / \mathrm{t} \text { ) }\end{array}$ \\
\hline $\begin{array}{l}\text { Umm } \\
\text { Egat }\end{array}$ & $\begin{array}{ll}\text { Chistosed } & \text { volcano- } \\
\text { sedimentary } & \text { deposits, } \\
\text { tonalite } & \end{array}$ & $0.3-40 \mathrm{~g} / \mathrm{t}$ \\
\hline $\begin{array}{l}\text { Umm } \\
\text { Garaiart }\end{array}$ & Metaandesitic tuffs & $\begin{array}{l}7.75-155.5 \\
g / t\end{array}$ \\
\hline Betam & $\begin{array}{l}\text { Schistosed metasediments } \\
\text { intercalated with tonalite- } \\
\text { granodiorite }\end{array}$ & $\begin{array}{l}2.0-11.07 \\
\mathrm{~g} / \mathrm{t}\end{array}$ \\
\hline
\end{tabular}

The Barramiya gold is one of the important gold deposits in central Eastern Desert. It locates in midway between Marsa Alam on the Red Sea coast and Idfu on the Nile bank. The deposit is restricted to gold-bearing quartz veins and neighboring alteration zone. Host rocks are mostly ophiolitic melange in which serpentinite in the western side is transformed autometasomatically into talc-carbonate in the eastern and central sides. Average thickness of the quartz vein is about $1 \mathrm{~m}$ and spreads for approximately $800 \mathrm{~m}$. The alteration zone around the vein is approximately $6 \mathrm{~m}$ thick, and composes of intensively altered graphite and tremolite-actinolite schists with ferruginous, sercitization and kaolinazation. Listweanite was formed as bands and lenses as a result of amalgamation of silica and carbonate with gold-bearing spots. Average gold content in the quartz vein ranges between 1.59 and 2.74 $\mathrm{g} / \mathrm{t}$ with total reserve of 30 tons of gold [44]. The most significant recent gold mines in Egypt are: El Sukkary area (Centamine Limited, Pharaoh gold mine) and Hamash area (Hamash Company) (Table 8). Recently, gold has been discovered at Uwaynat, G. Nazar and G. Kamel areas. The gold content in these areas is up to 14 $\mathrm{g} / \mathrm{t}$ [45].

Most placer gold deposits are close to the auriferous quartz veins as a result of arid and hot climate of the Egyptian deserts resulted in physical weathering. Two major categories of placer gold have formed in Egypt, the modern placers and lithified placers [39]. Recent placers are divided to beach and alluvial placers.

Table 8. Recent active gold mine in Egypt, El Sukari and Hamash regions (data from [46].

\begin{tabular}{|l|l|l|l|}
\hline \multicolumn{2}{|l|}{ Area } & Grade g/t & $\begin{array}{l}\text { Gold } \\
\text { content (M } \\
\text { oz. })\end{array}$ \\
\hline \multicolumn{1}{|l|}{ El Sukari } & 1.42 & 2.94 \\
\hline Hamash & Um Tondob & 0.8 & 1.2 \\
\cline { 2 - 4 } & Ara & 1.5 & 0.166 \\
\cline { 2 - 4 } & $\begin{array}{l}\text { Hamash old } \\
\text { mine }\end{array}$ & $2-4$ & 0.022 \\
\cline { 2 - 4 } & Abu Tarda & $1.5-5$ & 0.32 \\
\hline
\end{tabular}

The major accumulation of gold in a mechanically dispersed form in the wadis of the Eastern Desert favors the collection of alluvial placers. Insignificant amounts of gold documented in some Egyptian black beach sands in beach placers on the Mediterranean Sea. Lithified placers occur in the conglomerate at the lower part of the Upper Proterozoic molasse deposits of the Hammamat unit and/or the basal part of the Upper 
Cretaceous Nubian Formation that superimposes the Precambrian basement rocks [39].

\subsubsection{Platinum group elements (PGE)}

PGE are usually associated with mafic-ultramafic rocks of ophiolite and some layered intrusions or concentrically-zoned mafic ultramafics (gabbro Akarem, Genina Gharbia, Abu Swyil). At the Akarem area, the mafic-ultramafic complex contains layered and peridotite gabbroic. The primary sulfide minerals in these rocks are chalcopyrite, pyrrhotite, cubanite and pentlandite that show disseminated, net and massive textures in the olivine-rich ultramafic host rocks. Secondary minerals include violarite, monoclinic, pyrite, pyrrhotite, magnetite, millerite and mackinawite. Platinum $(<2 \mathrm{ppb})$ is determined in these sulfide minerals, also far below bulk levels (20-330 ppb). Coarse-grained pyrrhotite contains more $\mathrm{Rh}$ (20-120 ppb, average $60 \mathrm{ppb}$ ) than bulk rock (average $20 \mathrm{ppb}$ ) and other main sulfide minerals. Sulfides and bulk samples have much less Ir (a few ppb) than coarse pyrrhotite (30-100 ppb, average $60 \mathrm{ppb}$ ). Coarsegrained pentlandite contains the highest $\mathrm{Pd}$ concentrations, up to $1030 \mathrm{ppb}$ [4].

Electron microprobe (EPMA) analysis of the merenskyite-melonite series, Eastern Desert designated that range of the Pd concentrations are 12.6-22.9, 6.515.5, and 10.3-24.2 wt. \% in the Gabbro Akarem, Genina Gharbia, and Abu Swayel areas of the Eastern Desert, respectively [29]. The Pd-bearing minerals; the melonite group minerals, present at the interface between primary and secondary silicates, along crack in pentlandite, in secondary silicates in contact with pyrrhotite, held in cubanite lamellae in chalcopyrite, and at the boundary of chalcopyrite in a chlorite matrix (Fig. 13) [29].

PGE mineralization was also described in the podiform chromites from the late Proterozoic PanAfrican ophiolites in the Eastern Desert. The occurrences of platinum-group minerals (PGM) in the southern Eastern Desert (e.g. Abu Dahr, Abu Syeil, Belmhandite, Arais, and Um-Thagr areas) and central Eastern Desert (e.g. Wadi El-Zarka, Wadi El-Lawi, Um-Huitate, Wadi Bezah, Gebel El-Rubshi and Barramiya areas) chromitites are reasonably distinguishable; they are mostly Os-Ir alloy in the former (Fig. 14 A-C), and sulfides (Os-rich laurite) in the latter (Fig. 14 D-E).

Arsenides and sulfarsenides are also found in subordinate quantities in both chromites [47].
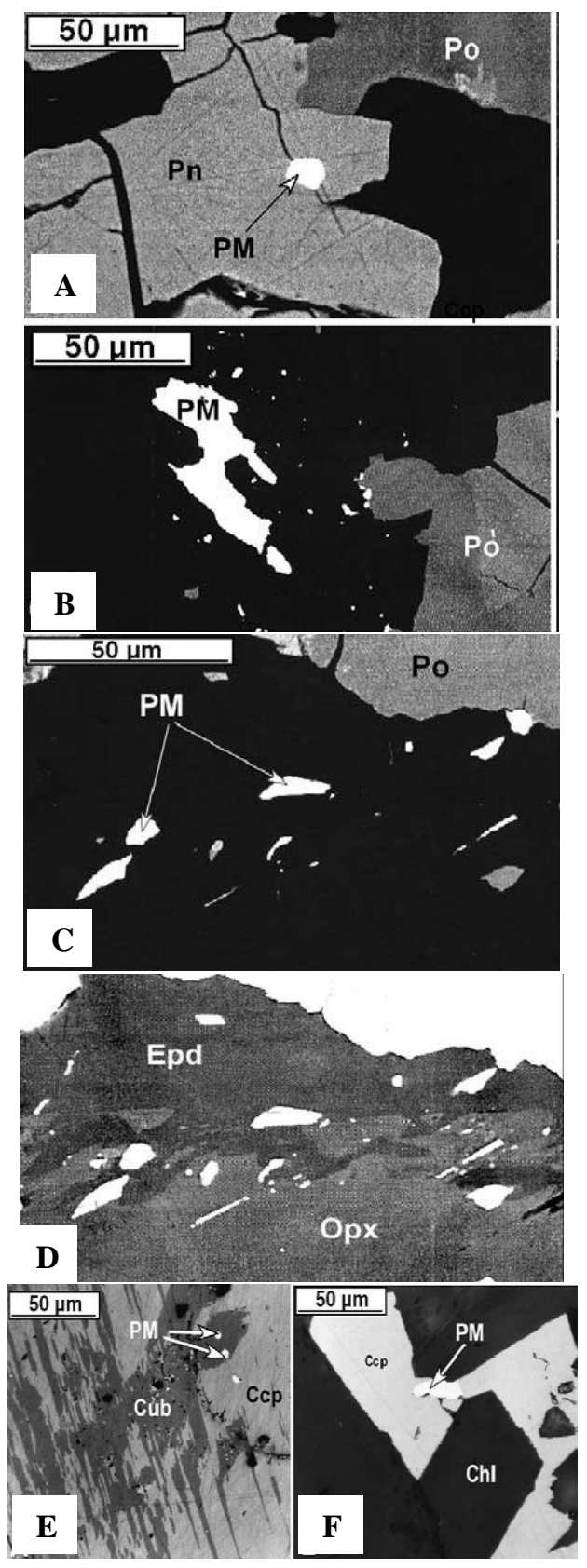

Fig. 13 BSE images of PGE-bearing minerals from Abu Swayel and Genina Gharbia areas. A) Pd-Bi melonite (PM) along cleavage in pentlandite (Pn). B) Pd-Bi melonite (PM) and other tellurides (small white grains) in secondary silicates (black) in contact with pyrrhotite. C) at the contact between orthopyroxene (Opx) and secondary epidote (Epd) illustrated in (D). E) $\mathrm{Pd}-\mathrm{Bi}$ melonite $(\mathrm{PM})$ presented in cubanite $(\mathrm{Cub})$ lamellae in chalcopyrite (Ccp). F) Pd-Bi melonite (PM) at the boundary of chalcopyrite in a chlorite (Chl) matrix [29]. 
Table 9 summarizes the EPmA analyses of PGEbearing phases in the southern and central Eastern Desert chromites [47]. Table 9 shows selected microprobe analyses of PGE-bearing phases (Wt. \%) in the southern and central Eastern Desert chromites of Egypt [47].

\subsection{Fissionable elements}

Fissionable elements in Egypt including $\mathrm{U}$ and $\mathrm{Th}$ occur in several localities mainly in the basement complex of the Eastern Desert (Fig. 15).
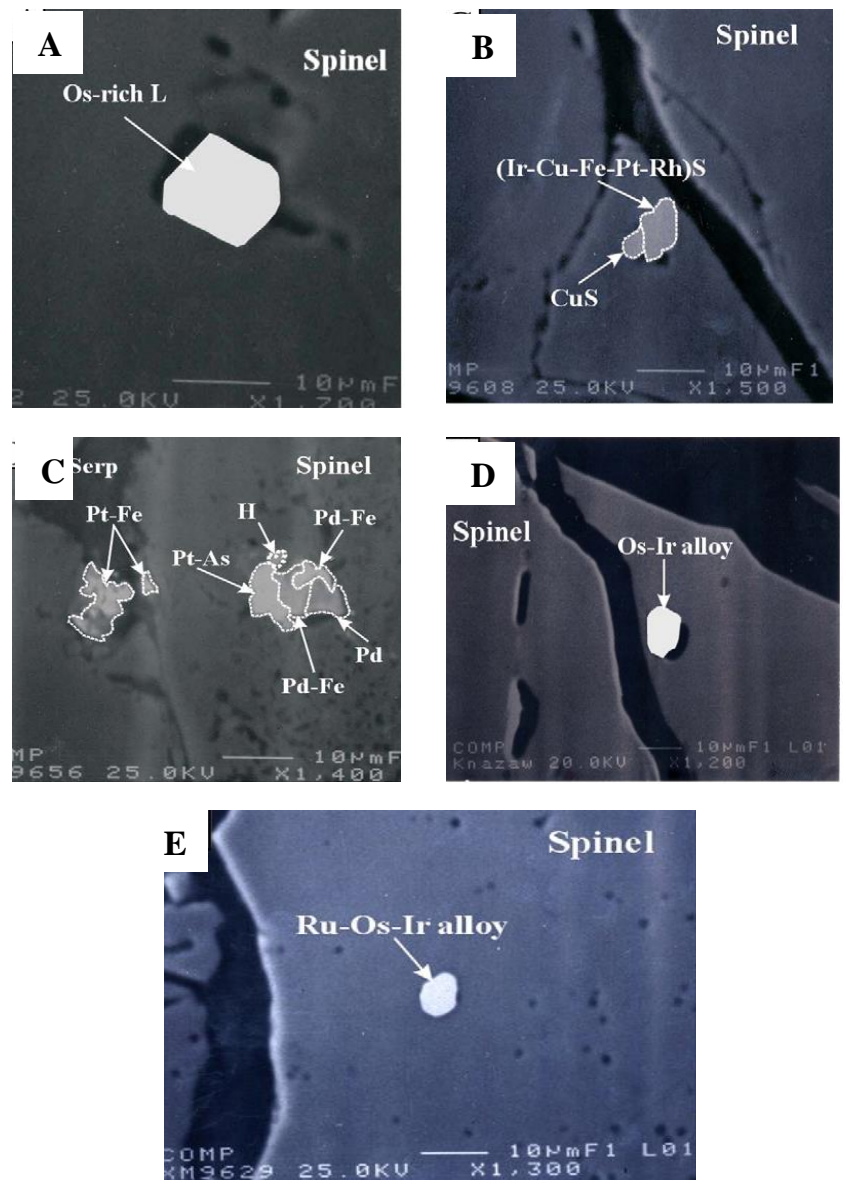

Fig. 14 BSE images of PGM in the chromites. A) euhedral Os-rich laurite crystals in chromian spinel. B) (Ir-Cu-Fe-Pt-Rh)S combined with $\mathrm{CuS}$ in chromian spinel. C) Composite PGM crystals having Pt-Fe alloy, Pd-Fe alloy, sperrylite (Pt-As), native $\mathrm{Pd}$ and hollingworthite $(\mathrm{H})$ in chromian spinel. D) euhedral Os-Ir alloy in fresh chromian spinel from Belmhandite. E) Ru-Os-Ir alloy in fresh chromian spinel [47].

\subsubsection{Uranium}

Dawood [48] reported a secondary uranium deposit at Um Ara region, Eastern Desert with U concentration varies from 0.15 to 20.3 wt. \%. U-bearing minerals occur mainly as uranophane and b-uranophane (Fig. 16) in the oxidized horizons as idiomorphic crystals filling voids and as coatings on the crack surfaces of the albitized and alkali-feldspar granites.

Table 9. Selected microprobe analyses of PGE-bearing phases (Wt. \%) in the southern central and Eastern Desert chromitites of Egypt (data from [47].

\begin{tabular}{|l|l|l|l|l|l|}
\hline $\begin{array}{l}\text { PG } \\
\text { E }\end{array}$ & $\begin{array}{l}\text { Sulfi } \\
\text { des }\end{array}$ & $\begin{array}{l}\text { Os-Ir } \\
\text { alloy }\end{array}$ & $\begin{array}{l}\text { Ru- } \\
\text { Os-Ir } \\
\text { alloy }\end{array}$ & $\begin{array}{l}\text { Sulfarseni } \\
\text { des }\end{array}$ & Arsenides \\
\hline Os & 27.9 & 70.8 & 17.4 & 0.1 & nd \\
\hline Ir & 5.6 & 21.9 & 14.1 & 53.6 & nd \\
\hline $\mathrm{Ru}$ & 29.9 & 4.8 & 62.6 & 3.1 & nd \\
\hline $\mathrm{Rh}$ & 0.7 & 0.2 & 3.6 & 3.1 & 1.9 \\
\hline $\mathrm{Pt}$ & $\mathrm{nd}$ & $\mathrm{nd}$ & $\mathrm{nd}$ & 0.6 & 47.4 \\
\hline $\mathrm{Pd}$ & 0.26 & 0.3 & $\mathrm{nd}$ & $\mathrm{nd}$ & 11.5 \\
\hline
\end{tabular}

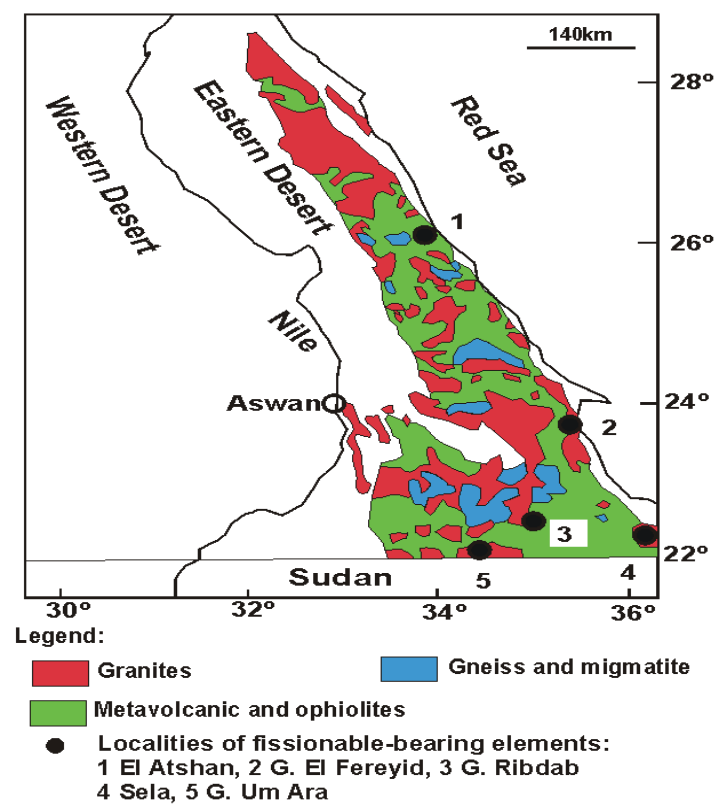

Fig. 15 Geological map of the basement complex in Egypt showing the locations of potential occurrences of fissionable elements (modified from [20]).

According to Dawood et al. [49], trachyte from El Atshan area has higher $U$ contents (67-1280 ppm) as a 
result of supergene enrichments of $U$ due to the weathering of trachyte in this area. Therefore, $\mathrm{U}$ in this area occurs as secondary U-bearing minerals. Chemical analysis of the secondary uranium deposit from El Atshan region revealed approximately $7.7 \mathrm{wt}$. \% of U.

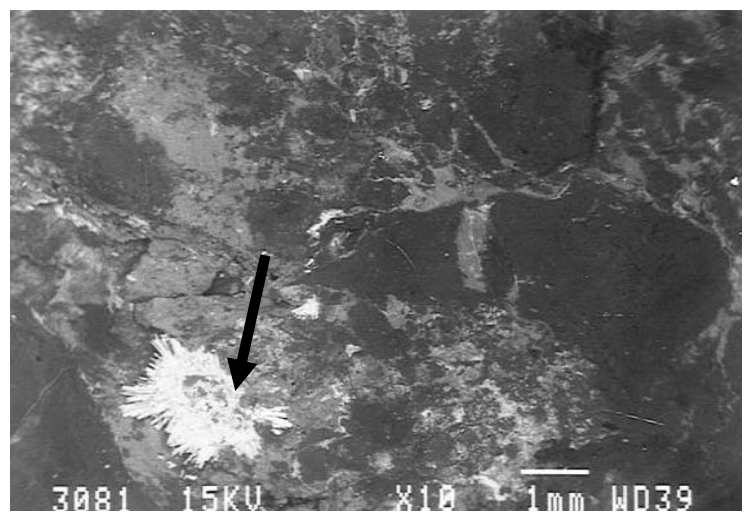

Fig. 16 SEM of cluster of needle-shaped uranophane crystals (arrow) filling a voids in the host granites [48].

Abd El-Naby and Dawood [50] examined the natural decrease of $U$ during low temperature alteration of the Sela granite, south Eastern Desert. They pointed out that a pre-existing hydroxyapatite was altered to autunite by an unidentified intermediate mineral phase (Fig. 17). $\mathrm{UO}_{3}$ contents in the hydroxyapatite vary from 5.6 to $9.5 \mathrm{wt}$. \% and in the intermediate phase from 23.4 to 40 wt. $\%$, while in the autunite range between 57.6 and $67.6 \mathrm{wt}$. \%. Ibrahim et al. [51] reported three types of secondary uranium minerals in the two mica granite of Gabal Ribdab region, South Eastern Desert, namely uranophane, becquerelite and zippeite (Fig. 18). Zippeite $\left[2 \mathrm{UO}_{3} \cdot \mathrm{SO}_{3} \cdot \mathrm{nH}_{2} \mathrm{O}\right]$ is an orange mineral and formed as stains on mafic minerals and iron oxides. Becquerelite $\left(2 \mathrm{UO}_{3} .3 \mathrm{H}_{2} \mathrm{O}\right)$ is yellow in color and coexists with uranophane.

Uranophane $\left[\mathrm{Ca}\left(\mathrm{UO}_{2}\right)_{2}\left(\mathrm{SiO}_{3}\right)_{2}(\mathrm{OH}) 2.5 \mathrm{H}_{2} \mathrm{O}\right]$ is also yellow in color and presents as soft aggregates on muscovite and quartz. The three minerals are considered as the alteration product of primary Ubearing minerals and associated with carbonatization and hematitization processes. The average of $U$ content in the two-mica leucogranite is $20 \mathrm{ppm}$ (range: $4-140$ $\mathrm{ppm}$ ), that in muscovite flakes is $11 \mathrm{ppm}$ (range: 1-30 $\mathrm{ppm}$ ) and that in the muscovite pegmatitic granite is 13 ppm (range: 2-40).
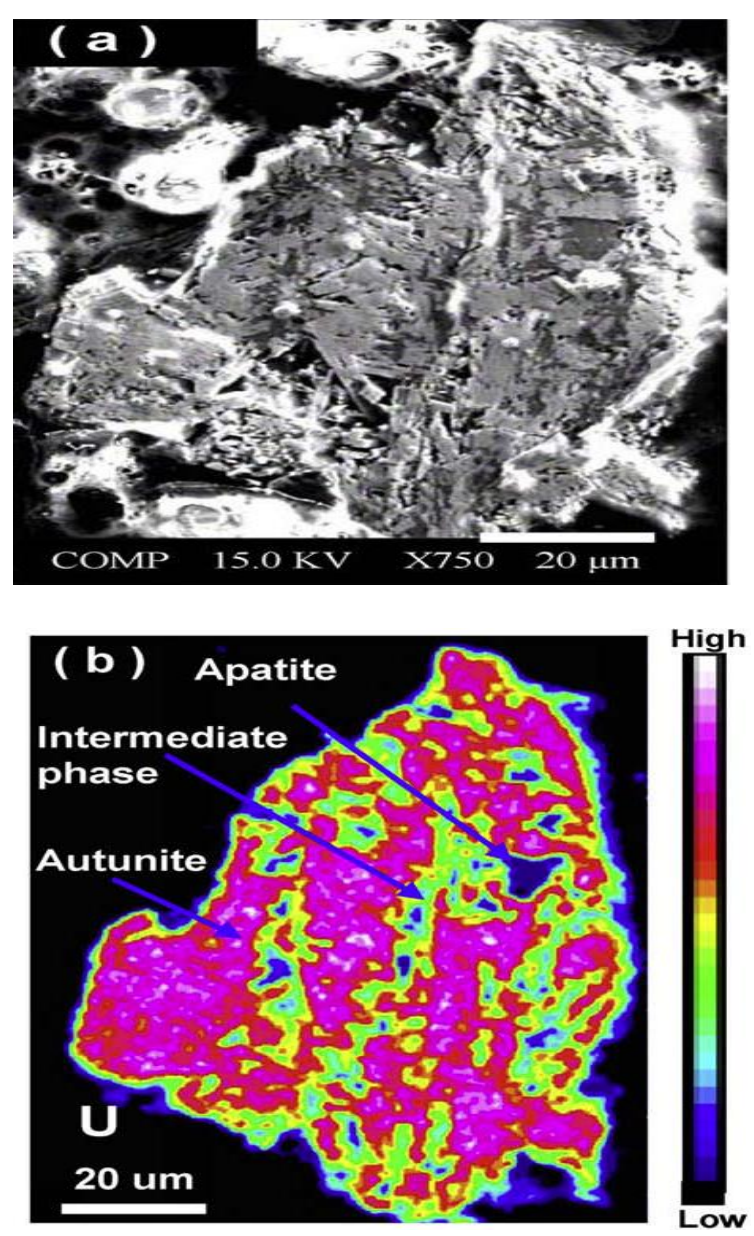

Fig. 17 A) BSE image illustrates subparallel tabı crystals of autunite hosting hydroxyapatite laths. B) ray maps of $\mathrm{U}[50]$.

Meta-autunite, boltwoodite, uranophane and soddyite occur as yellow crusts and acicular crystals (Fig. 19) in the fractures, voids and shear zones in the psammitic gneisses of the Abu Rusheid area, Eastern Desert [48]. $\mathrm{UO}_{2}$ contents at the meta-autunite vary between 68.5 and $76.3 \mathrm{wt}$ \% , in the uranophane range between 64.2 and $67.3 \mathrm{wt} . \%$, in the boltwoodite range between 58.3 and $63 \mathrm{wt} . \%$, and in the soddyite range between 54.3 and 71.4 wt. \%. At the Kab Amiri area, Central Eastern Desert, El-Hussaini et al. [15] reported high concentrations of $\mathrm{U}$ in the monsogranite (Table 10).

Feldespathized nepheline syenites in the inner parts of El Naga, Nigrub, El Fogani, and Abu Khrug areas, Eastern Desert are associated with relatively high concentrations of U (130-520 ppm) [28]. 

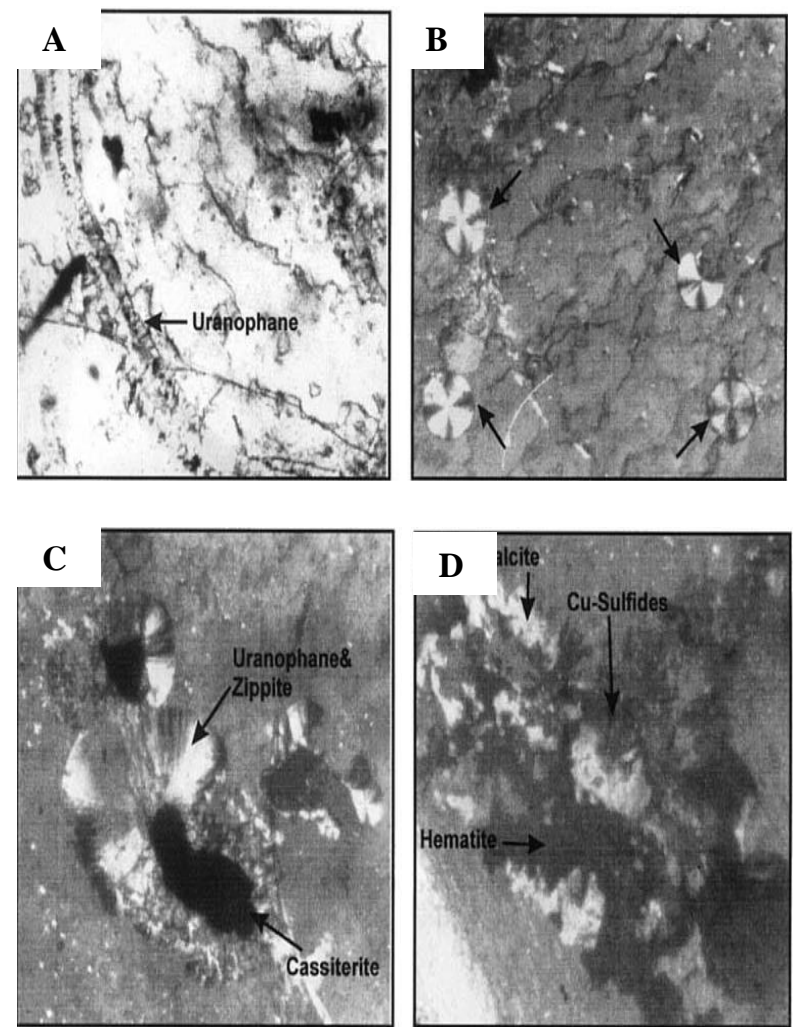

Fig. 18 A) Veinlet of uranophane mineral filling fractures in muscovite. B) Open filling uranophane in muscovite. C) Secondary U-bearing minerals associate with cassiterite. D) Hematite, $\mathrm{Cu}$-sulfides and calcite coexist with the uranium minerals [51].

Table 10. $\mathrm{U}_{2} \mathrm{O}_{8}$ at the $\mathrm{Kab}$ Amiri area in different grain sizes (data from [15]).

\begin{tabular}{|l|l|l|}
\hline Grain Size $(\mu \mathrm{m})$ & Weight $(\%)$ & $\mathrm{U}_{2} \mathrm{O}_{8}(\%)$ \\
\hline-500 & 8.2 & 17.5 \\
\hline-420 & 6.6 & 12.5 \\
\hline-297 & 6.1 & 9.0 \\
\hline-250 & 10.6 & 13.3 \\
\hline-125 & 17.2 & 17.5 \\
\hline-74 & 51.3 & 30.1 \\
\hline
\end{tabular}

Uranium in the Abu Tartur phosphorites ranges from 15 to $34 \mathrm{ppm}$ (average $22 \mathrm{ppm}$ ) [12], which is lower than that in the Nile Valley (46-114) [53] and Red Sea phosphorites (35-143 ppm) [52]. Uranium probably cannot be considered as a possible byproduct as a result of its low concentrations (13-65 ppm) [53].
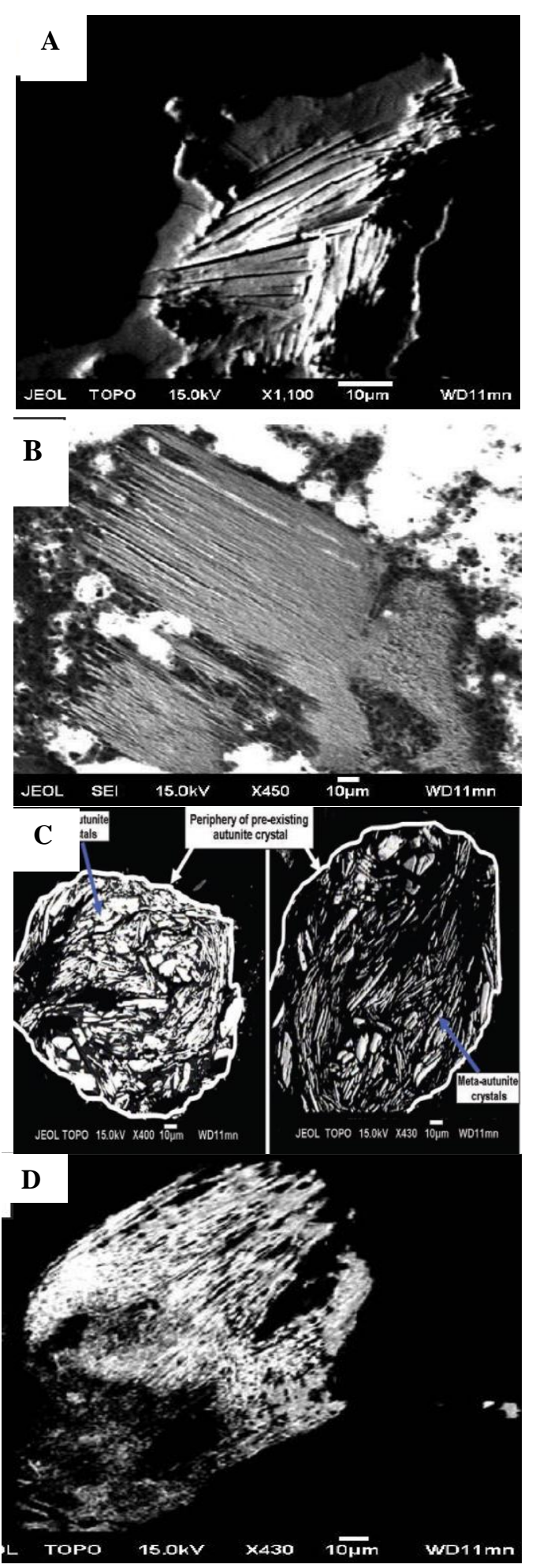

Fig. 19 A) BSE image illustrates fan-shaped uranophane crystals, B) bendable and thin metaautunite crystals, C) fibrous crystal clusters of soddyite, D) boltwoodite crystals [48]. 


\subsubsection{Thorium (Th)}

Monazite that is composed of REE and Th phosphate $\left((\mathrm{Ce}, \mathrm{La}, \mathrm{Nd}, \mathrm{Th}) \mathrm{PO}_{4}\right)$ in the black sands along the Mediterranean Sea Coast can be considered as one of the potential sources of Th in Egypt (see REE part). Abd El-Naby [54] identified a number of thorium existences in granitic rocks at the Um Ara area, south Eastern Desert. Thorite, U-rich thorite and zircon are the major primary $\mathrm{U}$ - and Th-bearing minerals in the mineralized horizones of the Um Ara alkali-feldspar granites, while uranophane is the most abundant secondary U-bearing mineral. U-rich thorite comprises galena, rims of uranophane and inclusions of $\mathrm{Zr}$-rich thorite (Fig. 20). $\mathrm{ThO}_{2}$ contents in the thorite grains range from 68.4 to 72.1 wt. $\%$, while $\mathrm{UO}_{2}$ contents range between 5.9 and 7 wt. \%.

At the Kab Amiri area, Central Eastern Desert, ElHussaini [15] reported high concentrations of Th in the monsogranite in addition to the $\mathrm{U}$ (Table 11). Feldespathized nepheline syenites in the inner parts of El Naga, Nigrub, El Fogani, and Abu Khrug areas, Eastern Desert are associated with anomalous concentrations of Th (1420-8400 ppm) [28].

\subsection{Processing and extraction of rare metals in Egypt}

Although rare metals are quite common in Egypt and some of these metals occur in association as the abovementioned review shows, processing and extraction attempts of these metals are very limited compared with the potential occurrences of these metals. As for beneficiations of the rare metals in Egypt, few published attempts have been found during this review. Abd El-Rahman et al. [55] studied the recovery of fine cassiterite from Igla placer deposits using falcon gravity separator and high intensity wet magnetic separation. Falcon separation concentrate containing $24.1 \% \mathrm{SnO}_{2}$ and recovery of $88.7 \%$ by weight $\mathrm{SnO}_{2}$ was obtained from a feed containing about $0.1 \% \mathrm{SnO}_{2}$ that were cleaned by wet high intensity magnetic separation to $87 \% \mathrm{SnO}_{2}$ and recovery of 95 $\% \mathrm{SnO}_{2}$. Although there are many attempts to upgrade the phosphorites in Egypt for the manufacturing of fertilizers and production of phosphoric acid [56,57,58], the processing of REE were not considered in these attempts.
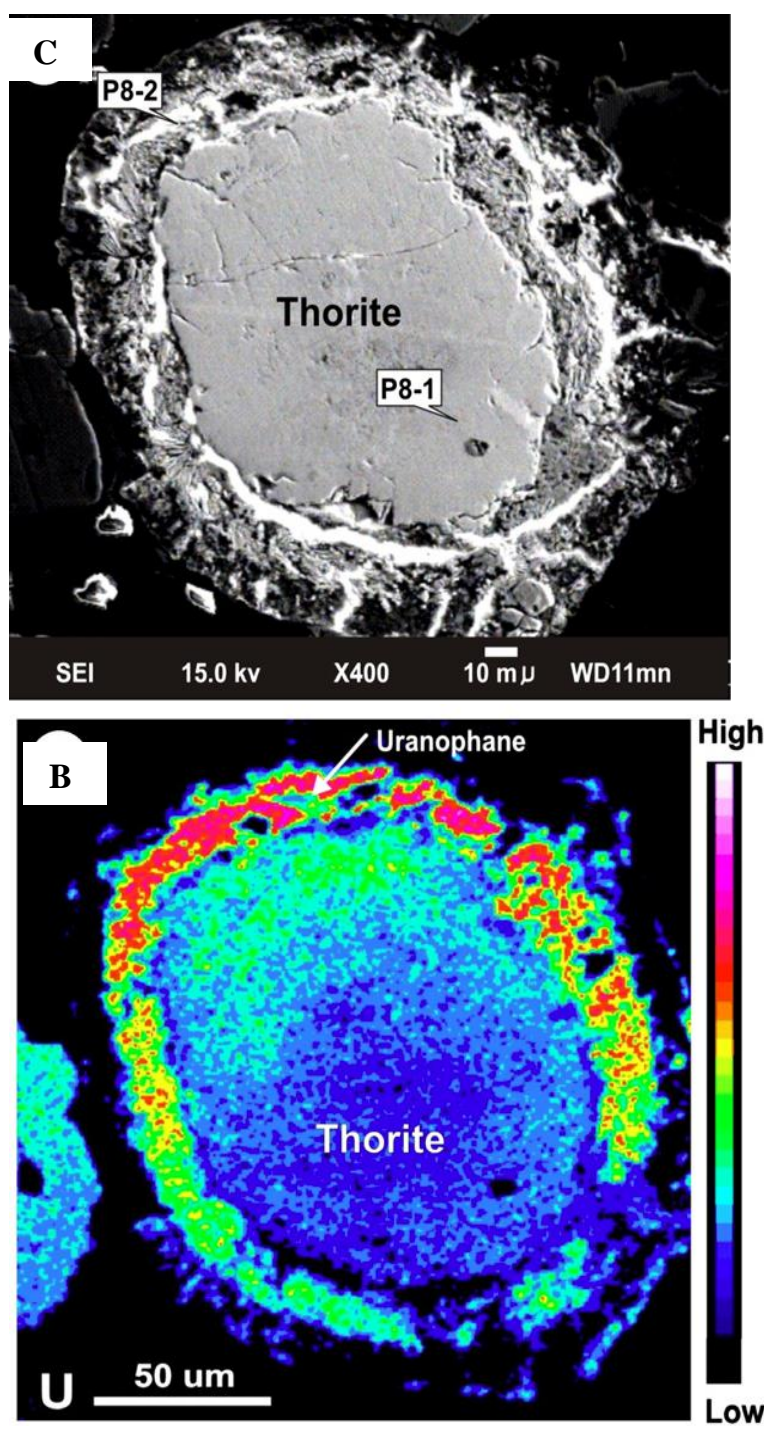

Fig. 20 A) Secondary electron image of thorite with uranophane rims. B) X-ray map of (A) for uranium, indicating zoning in the thorite [54].

Table 11. Distributions of $\mathrm{ThO}_{2}$ at the Kab Amiri area in different grain sizes (data from [15]).

\begin{tabular}{|l|l|l|}
\hline Grain Size $(\mu \mathrm{m})$ & Weight $(\%)$ & $\mathrm{ThO}_{2}(\%)$ \\
\hline-500 & 8.2 & 10.0 \\
\hline-420 & 6.6 & 7.8 \\
\hline-297 & 6.1 & 6.9 \\
\hline-250 & 10.6 & 10.6 \\
\hline-125 & 17.2 & 17.2 \\
\hline-74 & 51.3 & 47.5 \\
\hline
\end{tabular}


Moustafa and Abdelfattah [59] designed a flow sheet to concentrate monazite from Egyptian beach sands comprising around 30 wt. \% valued heavy minerals. In this flow sheet, low specific gravity gangue is removed by wet gravity concentration, then low intensity magnetic separation is applied to remove any ferromagnetic minerals without eliminating paramagnetic monazite. Rutile is removed as it reports to the conductor fraction after electrostatic separation (zircon and monazite are non-conductive) and then diamagnetic zircon is removed from the paramagnetic monazite using additional magnetic separation.

An attempt to extract rare metals from the Egyptian ores was conducted by El-Hussaini et al. [15]. In this study, the Kab Amiri Nb- and Ta-bearing granites were subjected to direct agitation leaching by sulfuric acid. When finely ground ore $(-74 \mu \mathrm{m})$ was reacted upon for $2 \mathrm{~h}$ with a combination of sulfuric acid $(10.8 \mathrm{M})$ and nitric acid $(5.3 \mathrm{M})$ in the ore to acid weight ratio of $1: 3$ at $200{ }^{\circ} \mathrm{C}$, almost comprehensive recovery of both $\mathrm{Nb}$ and Ta was reached while the leaching degrees of Th and total REEs were $86 \%$ and $70 \%$, respectively. Alternatively, the recovery of both $\mathrm{U}$ and $\mathrm{Ti}$ did not more than $60 \%$ as a result of their occurrence in the refractory mineral davidite. $\mathrm{Nb}$ and $\mathrm{Ta}$ have been separated from the leach liquor using the tertiary amine, Alamine 336, by kerosene and xylene as diluents and ndecanol as a modifier [60].

As to the commercial scale of rare metals extraction, the only successful attempts to extract rare metals in Egypt are limited to the exploration and extraction of gold from a number of mines in the Sukkary (Centamine Limited) and Hamash (Hamash Co.) areas, Eastern Desert. In both areas, commercial production has just started using surface, open pit-open cast mining techniques $[14,61]$.

\section{Discussion}

The rare metals were classified into four classes based on their chemical properties including rare earth, trace, noble, and fissionable elements in order to discuss their occurrences, industrial uses, and market. However, the critical review of the rare metals in Egypt suggested another classification in Egypt based on their host rocks to maximize the possible industrial utilization of the rare metals as well as their host rocks and minerals. The classification include three associations: 1) rare metals hosted by granites, 2) rare metals associate the mafic rocks and ophiolites, and 3) rare metals occur in the sedimentary rocks.

Granites are extensively distributed in the Eastern Desert and Sinai as part of the Precambrian basement complex of Egypt [20] including the albite-granites. According to the abovementioned review, these granites include numerous numbers of rare metals such as REE in the Kab Amiri area, gold and silver in more than 95 localities mainly in the granites, niobium and tantalum in the granites at the Jabal Gattar and albitegranites at the Abu Dabbab, Nuweibi, Um Naggat, Abu Rashid, and Kab Amiri areas, uranium at the granites of the Um Ara, El Atshan, Gabal Ribdab, Abu Rusheid, El Naga, Nigrub, El Fogani, and Abu Khrug areas, TinTungsten-Molybdenum association at the granites of the Igla, Abu Marwa, Gattar, Abu Harba, Um Disi and Homer Akarm, Abu Dabbab, Abu Hammad, and Um Bisilla, Muelha, Fatira, Abu Kharif, and Nuweibi areas, and thorium at the granites of the Um Ara an, Kab Amiri area. In addition to the rare metals contents of these granites, these granites are composed of feldspars especially albite in the albite-granites, quartz and mica (muscovite and biotite). Therefore, the utilizations of these granites for possible extraction of these metals can also include the extraction of these minerals that have many industrial applications such as abrasive, crucibles, computers, mobile phones, wristwatches, clocks, radios, navigational instruments, and television receivers for quartz and glass and ceramics industries for the feldspars, and paint, drywall compound, electronics, plastic, filler, and rubber for micas. Although the literatures showed that Kap Amiri granites have high concentrations of REE, NB, Ta, U, and $\mathrm{Th}$, which makes these granites as potential source of these metals, the reserves, mineralogy, and mode of occurrence of these metals are not clear.

Mafic rocks and ophiolites represent a major portion of the Precambrian basement complex in Sinai and Eastern Desert [29,47]. Some important rare metals occur in these rocks such as cooper-nickel-cobalt association at the gabbro of the Abu Swayel, El Geneina, and Gabbro Akarem areas as well as the platinum group metals (PGM). These rocks are composed of gabbros and sometimes associated with chromite, serpentine, magnesite, and talc. Therefore, the utilizations of these mafic rocks and ophiolites for possible extraction of the cooper-nickel-cobalt-PGE can also include the utilization of the associated minerals that have industrial applications such as refractory and stainless steel for chromite, plastic, paper making, paint 
and coatings, rubber, electric cable, food, pharmaceuticals, cosmetics, and ceramics for talc, decorative stone and carving stone tools for serpentine, and slag former in steelmaking furnaces, and binder in flooring materials.

Sedimentary rocks-bearing rare metals in Egypt are mainly phosphorites, black sands, and black shales. Phosphorites are one of the major deposits in Egypt ( 3 billion tons' reserves) (Notholt, 1985; 9] are exploited for domestic industries and export as raw materials from different areas via several companies such as Red Sea Phosphorite Co. (Red Sea phosphorites), Abu Zabaal Phosphate Co. (Nile Valley phosphorites), and Phosphate Misr Co. (currently at Abu Tartur area). However, the attempts to extract REE from these phosphorites are almost absent to the best knowledge of the author. The extraction of REE from the phosphorites requires detail investigations on the behaviors of these elements during the different treatments and steps of utilizations. For example, during the chemical treatments of the phosphorites to produce phosphoric acid, it is important to follow the fractionations and forms of REE in the ore itself, in the phosphoric acid, and/or in the phosphogypsum cake. According to Habashi [62], when the phosphorite rock is treated with $\mathrm{H}_{2} \mathrm{SO}_{4}$, the lanthanides are mostly $(\sim 70$ $\%$ ) missed in the gypsum filtrate. When the phosphorite is treated with $\mathrm{HNO}_{3}$ or $\mathrm{HCl}$, more than $80 \%$ can be recovered without interference with fertilizer production. The extraction of REE from the phosphorites can be part of integrated industrial plant that can produce fertilizers, phosphoric acid, gypsum, and REE. In the Red Sea area, these phosphorites are associated with black shales beds with relatively high organic matter. This organic matter is rich in vanadium [37] that can add another economic value to the phosphorites and the associated black shales.

Large reserves of black sands occur along the Mediterranean Sea coast [13]. These black sands are composed of several minerals like ilmenite, magnetite, hematite, rutile, zircon, and monazite (REE- and Thbearing mineral). Therefore, the utilizations of these black sands for possible extraction of the REE and Th can also include extraction of these minerals that are considered as potential sources of metals such as $\mathrm{Ti}$ from the rutile and ilmenite, Fe from the hematite and magnetite, and $\mathrm{Zr}$ from the zircon. These metals have numerous industrial applications such as steel and its alloys for Fe; manufacture of wide diversity of metal parts where very high strength and light weight are required like artificial joints for humans, aircraft parts and sporting tools such as bicycle frames from Ti; and variety of high temperature applications for $\mathrm{Zr}$. Thus, the integrated utilizations of these metals in addition to the rare metals can add significant values to the black sands deposits in Egypt. Although these black sands occur in relatively large reserves and can be exploited easily, only few published attempts have been found during this review on processing of these sands to extract valuable metals and elements [59] and almost nothing was found about the distribution of REE and Th in these black sands. The presence of some radioactive elements (Th and probably $U$ ) that needs special laboratory precautions to deal with these deposits could be the reasons behind the lacking of publications on these black sands in the international level like many other mineral deposits in Egypt.

It is well known that the geology of Sinai Peninsula is very similar to that in the Eastern Desert especially for the Precambrian basement complex [20,63]. Therefore, potential occurrences of rare metals are expected in Sinai especially those hosted by the granites such as REE, Au, Nb, Ta, Sn, and W. The current work noticed lacking of published data on the occurrences of rare metals in Sinai.

\section{Conclusions}

The critical review of rare metals in Egypt revealed the following conclusive remarks.

1- Rare metals are quite common in Egypt including rare earth, trace, noble, and fissionable elements.

2- Some of these metals occur in association in the same rock and ore such as REE-Th, Nb-Ta, Cu-NiCo, Au-Ag, and U-Th.

3- One rock can host variety of rare metals such as granites that are widely spread in the Eastern Desert and Sinai, hosts Au, Ag, REE, U, Nb, Ta, Th, Sn, W, and Mo.

4- These metals associate with other minerals of industrial applications like REE in the phosphorites and $\mathrm{Nb}$ and $\mathrm{Ta}$ with quartz, feldspars, and mica.

5- Processing and extraction attempts of these metals in Egypt are very few compared with the potential occurrences of these metals.

6- Phosphorites deposits, as a major potential resource of REE in Egypt, occur in large reserves ( 3 billion tons) and are exploited from many localities. However, no attempts have been found to extract the REE from these phosphorites.

7- Although black sands are considered as one of the major natural resources of rare metals such as REE, 
Th, and $\mathrm{Zr}$, no published data were found about the rare metals contents or economic feasibility of these black sands and their rare metals contents.

8- The literatures showed that Kap Amiri granites have high concentrations of REE, NB, Ta, U, and Th, which makes these granites as potential source of these metals. However, the reserves, mineralogy, and mode of occurrence of these metals are not clear.

9- No publications about occurrences of rare metals in Sinai Peninsula although it is expected to have potential occurrences of these metals since its geology is very alike to that of the Eastern Desert.

10 -The commercial scale of rare metals utilization is limited to the exploration and extraction of gold from a number of mines in the Eastern Desert.

\section{References}

[1] S. Behrendt, M., Scharp, and L. Erdmann, Rare metals Measures and concepts for the solution of the problem of conflict-aggravating raw material extraction-the example of coltan. Walter Kahlenborn, Moira Feil, Cornelia Dereje Adelphi Research GmbH, Berlin (2007) Pp 68.

[2] M. Nakamura, AIST Rare Metal Task Force, National Institute of Advanced Industrial Science and Technology (2008) Pp. 12.

[3] G.J. Simandl, Geology and market-dependent significance of rare earth element resources, Mineral. Depos. 49(8) (2010) 889-904.

[4] K. Bourzac, The Rare-Earth Crisis. Tech. Rev. Manch. Nh-114(3) (2001) 58-63.

[5] R. Eggert, C. Wadia, C.G. Anderson, D. Bauer, F. Fields, L.D. Meinert, R. Patrick, and P.R. Taylor, Rare Earths: Market Disruption, Innovation and Global Supply Chains, Ann. Rev. Envir. Res. 41(1) (2010) 15-26.

[6] G.I. Spanderashvilli, M. Mansour, The Egyptian phosphorites. In: Moharram, O. (Ed.), Studies on Some Mineral Deposits of Egypt, UAR Geol. Surv. (1970) 89-106.

[7] S.M. Jasinski, Phosphate rock. Unit. St. Geol. Surv. Min. Year. 56 (2003) 1-56.

[8] H.M. Baioumy, Forms of iron in the late Cretaceous phosphorites in Abu-Tartur area Egypt, J. Chin. Geoch. 3 (2002) 215-226.

[9] H.M. Baioumy, and R. Tada, Origin of Upper Cretaceous phosphorites in Egypt, Cret. Res. 26 (2005) 261-275.
[10] H.M. Baioumy, R. Tada, and M. Gharaie, Geochemistry of Late Cretaceous phosphorites in Egypt: implication for their genesis and diagenesis, J. Afr. Eart. Sci. 49 (2007) 12-28.

[11] H.M. Baioumy, Rare earth elements and sulfur and strontium isotopes of upper Cretaceous phosphorites in Egypt, Cret. Res. 32, (2011) 368377.

[12] G.S. Awadalla, Geochemistry and microprobe investigations of $\mathrm{Abu}$ Tartur REE-bearing phosphorite, Western Desert, Egypt, J. Afr. Eart. Sci. 57 (2010) 431-443.

[13] G. Naim, E.T. El Melegy, and A. El Azab, Black Sand Assessment, Egyp. Geol. Surv. (1993) Pp. 67.

[14] A.M. Abouzeid, and A.M. Khalid, Mineral Industry in Egypt-Part I: Metallic Mineral Commodities, Nat. Res. 2 (2011) 35-53.

[15] O.M. El-Hussaini, and M.A. Mahdy, Sulfuric acid leaching of Kab Amiri niobium-tantalum bearing minerals, Central Eastern Desert, Egypt, Hydrom. 64 (2002) 219-229.

[16] N.I, Abd El Ghaffar, Enrichment of rare earth and radioactive elements concentration in accessory phases from alkaline granite, South Sinai- Egypt, J. Afr. Eart. Sci. 147 (2018) 393-401.

[17] A. El-Taher., W.M. Badawy, E.M. Ashraf, A.E.M., Khater, A. Hashem, and H.A. Madkour, Distribution patterns of natural radionuclides and rare earth elements in marine sediments from the Red Sea, Egypt, Appl. Rad. Iso. 151 (2019) 171181.

[18] K.M. Hassan, Trace elements and REE enrichment at Seboah Hill, SW Egypt, Mineral. 49(1-4) (2018) 47-65.

[19] G.M. Saleh, A.M. Afify, B.M., Emad, M.I. Dawoud, H.A. Shahin, and F.M. Khaleal, Mineralogical and geochemical characterization of radioactive minerals and rare earth elements in granitic pegmatites at G. El Fereyid, South Eastern Desert, Egypt, J. Afr. Ear. Sci. 160 (2019) 103651.

[20] K.A. Ali, R.J. Stern, W.I. Manton, J.I. Kimura, H.A. and Khamees, Geochemistry, $\mathrm{Nd}$ isotopes and U-Pb SHRIMP zircon dating of Neoproterozoic volcanic rocks from the Central Eastern Desert of Egypt: New insights into the 750Ma crust-forming event, Precam. Res. 171 (2009) 1-22. 
[21] H. Helba, R.B. Trumbull, G. Morteani, S.O. Khalil, and A. Arslan, Geochemical and petrographic studies of Ta mineralization in the Nuweibi albite granite complex, Eastern Desert, Egypt. Miner. Dep. 32 (1997) 164-179.

[22] D. Küster, Granitoid-hosted Ta mineralization in the Arabian-Nubian Shield: Ore deposit types, tectono-metallogenetic setting and petrogenetic framework, Ore Geol. Rev. 35 (2009) 68-86.

[23] Gippsland Limited, Tantalum Industry Overview, Ann. Rep. (2005) Pp. 58.

[24] K.M. Hassan, Trace elements and REE enrichment at Seboah Hill, SW Egypt, Miner. 49(1-4) (2018) 47-65.

[25] A.M. El-Kammar, A.E. Salman, M.H. Shalaby, and A.I. Mahdy, Geochemical and genetical constraints on rare metals mineralization at the central Eastern Desert of Egypt, Geoch. J. 35 (2001) 117-135.

[26] M.F. El-Ramly, and A.A.A. Hussein, The ring complexes of the Eastern Desert of Egypt, J. Afr. Ear. Sci. 3(1/2) (1983) 77-82.

[27] A.H. Hashad, Present status of geochronological data on the Egyptian basement complex. In: AlShanti AMS (eds.) Evolution and mineralization of the Nubian-Arabian Shield, 3 (1980) 31- 46.

[28] A.A. Hussein, Mineral deposits. In: Said, R. (Ed.), The Geology of Egypt. Balkema, Rotterdam, (1990) 511-566.

[29] H.M. Helmy, Melonite group minerals and other tellurides from three $\mathrm{Cu}-\mathrm{Ni}$-PGE prospects, Eastern Desert, Egypt, Ore Geol. Rev. 26 (2005) 305-324.

[30] T.M. Ramadan, and I.M. Shalaby, Cu-Ni-PGE Mineralization in the Arabian-Nubian Shield, South Eastern Desert, Egypt, Using Remote Sensing Approach. 11th International Platinum Symposium June 21-24, 2010 Ontario Geological Survey, Miscellaneous Release-Data 269 (2010) 14.

[31] E.M. El-Shazly, Classification of Egyptian mineral deposits, Egy. J. Geol. 1 (1957) 1-20.

[32] G.L. Nassim, The discovery of nickel in Egypt, Eco. Geol. 44 (1949) 143-150.

[33] W.F. Hume, and R.H. Greaves, Geology of Egypt, 2. Government Press (1937) Pp. 297.

[34] A. Dardir, and S. Gadalla, Geology of molybdenite deposits between Lat. 2700 and 27 30' N (Eastern Desert of Egypt), Internal report (1969) Pp. 112.
[35] D. Searle, Final report on the geology and assessment of the Mo prospect of Homr Akarem. Internal Report, Geological Survey of Egypt (1974) Pp. 67.

[36] T. Anwar, M.A. Morsy, A.I. Arslan, and M.A. El Maky, Estimation of the Probable Geological Reserve of Tin in the Igla Area, Eastern Desert, Egypt," Arab Mining and Petroleum Association Conference, Ismalia, Egypt (1983) Pp. 39.

[37] H.M. Baioumy, and S.I. Ismael, Factors controlling the compositional variations among the marine and non-marine black shales from Egypt, Int. J. Coal Geol. 83 (2010) 35-45.

[38] N.S. Botros, On the relationship between auriferous talc deposits hosted in volcanic rocks and massive sulphide deposits in Egypt, Ore Geol. Rev. 23 (2003) 223-257.

[39] N.S. Botros, Geological and geochemical studies on some gold occurrences in the north Eastern Desert, Egypt. PhD Thesis, Zagazig University, Zagazig, Egypt, (1991) Pp. 146.

[40] N.S. Botros, Stratiform gold deposits in a Proterozoic BIF, Abu Marawat area, Eastern Desert, Egypt. Eleventh Symp. On Precambrian and Development, Cairo, (1995a) Pp 1.

[41] A.A. Dardir, and K.A.M. Elshimi, Geology and geochemical exploration for gold in the banded iron formation of Um Nar area, Central Eastern Desert, Egypt, Ann. Geol. Surv. Egy. 18 (1992) 381-409.

[42] A.M. Ahmed, M.M. Said, M.M. El Baghdady, and G. Abdel Wahab, Mineral potential of the eastern part of Wadi Allaqi, south Eastern Desert, Egypt, Ann. Geol. Surv. Egy. 22 (2001) 451-462.

[43] N.S. Botros, Genesis of gold mineralization in the North Eastern Desert, Egypt, Ann. Geol. Surv. Egy. 20 (1995b) 381-409.

[44] EGSMA, Egyptian Geological Survey and Mining Authority, Egypt," Results of Prospecting and Provisory Work for Gold at Barramiya, Sukkary, Um Nar Prospects, Internal Report (1977) 19/77, 23-34.

[45] M. Khattab, O.R. Greiling, A.M. Khalid, M. Said, A. Kontany, and A. Abu Salem, Uwaynat Banded Iron Formation (SW Egypt) Distribution and Related Gold Mineralization, Ann. Geol. Surv. Egy. 25 (2002) 343-364.

[46] A.Z.M. Abouzeid, and M.A. El Wgeeh, Mineral Industry in Egypt-State of the Art. 11th 
International Mineral Processing Symposium, Belek, Antalya, Turkey (2008) Pp. 1-27.

[47] H.A. Ahmed, Diversity of platinum-group minerals in podiform chromitites of the late Proterozoic ophiolite, Eastern Desert, Egypt: Genetic implications, Ore Geol. Rev. 32 (2007) 119.

[48] Y.H. Dawood, Uranium-series disequilibrium dating of secondary uranium ore from the south Eastern Desert of Egypt, Appl. Rad. Iso. 55 (2001) 881-887.

[49] Y.H. Dawood, H.H. Abd El-Nabyb, and A.A. Sharafeldina,. Influence of the alteration processes on the origin of uranium and europium anomalies in trachyte, central Eastern Desert, Egypt, $J$. Geoch. Expl. 88 (2004) 15-27.

[50] H.H. Abd El-Naby, and Y.H. Dawood, Natural attenuation of uranium and formation of autunite at the expense of apatite within an oxidizing environment, south Eastern Desert of Egypt, Appl. Geoch. 23 (2008) 3741-3755.

[51] M.E. Ibrahim, Saleh, and H.H. Abd El-Naby, Uranium mineralization in the two mica granite of Gabal Ribdab area, South Eastern Desert, Egypt, Appl. Rad. Iso. 55 (2001) 861-872.

[52] R.S. Shahata, G.S. Awadalla, and R.M., El Gammal, Geochemical contributions to the phosphate rocks of the Thebes Formation at west and southwest Sinai, Egypt, In: 5th International Conference on Geochemistry, Alexandria University Egypt (2001) Pp. 115-130.

[53] F. Hassan, and A.M. El Kammar, Environmental conditions affecting the distribution of uranium and rare earth elements in Egyptian phosphorites, Egy. J. Geol. 19 (1975) 169-178.

[54] H.H. Abd El-Naby, High and low temperature alteration of uranium and thorium minerals, Um Ara granites, south Eastern Desert, Egypt, Ore Geol. Rev. 35 (2009) 436-446.

[55] M.K. Abd El-Rahman, M.A.Youssef, N.H. Helal, M.M. El- Rabiei, and S.R. Elsaidy, Experimental design technique on recovery of fine cassiterite from Igla placer ore of Egypt, J. Ore Dres. 11 (2009) 24-32.

[56] A.M. Abouzeid, Physical and thermal treatment of phosphate ores -An overview, Int. J. Min. Proc. 85 (2008) 59-84.

[57] A.Z.M. Abouzeid, A.T. Negm, and D.A. Elgillani, Upgrading of calcareous phosphate ores by flotation: Effect of ore characteristics, Int. J. Min. Proc. 90 (2008) 81-89.

[58] M.I. Al-Wakeel, Effect of mechanical treatment on the mineralogical constituents of Abu Tartour phosphate ore, Egypt, Int. J. Min. Proc. 75 (2005) 101-113.

[59] M.I. Moustafa, and N.A. Abdelfattah, 2010. Physical and chemical beneficiation of the Egyptian Beach Monazite, Res. Geol. 60 (2010) 288-299.

[60] O.M. El-Hussaini, and N.M. Rice, Liquid-liquid extraction of niobium and tantalum from aqueous sulphate/fluoride solutions by a tertiary amine, Hydrom. 72 (2004) 259-267.

[61] M.M. Fawzy, N.M. Mahdy, and M. Sami, Mineralogical characterization and physical upgrading of radioactive and rare metal minerals from Wadi Al-Baroud granitic pegmatite at the Central Eastern Desert of Egypt, Arab. J. Geo. 13 (2020) 413-427.

[62] F. Habashi, The Recovery of the Lanthanides from Phosphate Rock, J. Chem. Tech. Biot. 35 (1985) 5-14.

[63] Y. Beeri-Shlevin, Y. Katzir, J.W. Valley, Crustal evolution and recycling in a juvenile continent: Oxygen isotope ratio of zircon in the northern Arabian Nubian Shield, Lith. 107 (2009) 169-184. 